OPEN ACCESS

Edited by:

Kay Fuller,

University of Nottingham

United Kingdom

Reviewed by:

Jennie Weiner,

University of Connecticut,

United States

Frank Hernandez,

Southern Methodist University,

United States

*Correspondence:

Sheralyn Cook

sheralyn.cook@waikato.ac.nz

Specialty section: This article was submitted to

Leadership in Education,

a section of the journal

Frontiers in Education

Received: 30 January 2020

Accepted: 14 May 2020

Published: 18 June 2020

Citation:

Cook S (2020) Put Your Big Girl Knickers on! The Experiences of Two

Female Leaders in New Zealand

Primary Schools Turning Schools

Around. Front. Educ. 5:78.

doi: 10.3389/feduc.2020.00078

\section{Put Your Big Girl Knickers on! The Experiences of Two Female Leaders in New Zealand Primary Schools Turning Schools Around}

\author{
Sheralyn Cook* \\ Division of Education, University of Waikato, Hamilton, New Zealand
}

This chapter examines the experiences of two female leaders in New Zealand state primary schools and their experiences of turning their schools around. Leading schools through times of change and challenge is complex, especially when issues of school underperformance and student achievement are intertwined. In some instances, such circumstances result in educational authorities imposing an intervention such as a "turnaround" program. Each year a small number of New Zealand schools are considered "underperforming" and require external leadership assistance, usually from the Ministry of Education. This support is implemented through a statutory intervention mechanism aimed to address underpinning issues such as governance and leadership matters, low student academic achievement, issues of finance, and student and staff safety and well-being (Ministry of Education, 2017). While statutory interventions have been enacted in New Zealand since 1994 as a mechanism to "turn a school around," there is little research about what this experience is like for educational leaders in primary (elementary) schools, or how it affects their professional and personal lives. Within the turnaround school literature, educational leaders are often positioned as "heroic leaders," usually male, seeking to change the school's climate and culture. However, there is little literature discussing how female educational leaders approach school recovery processes. With sparse acknowledgment of the effects this work has on a leader's professional and personal life, it is within these spaces that this research on female leaders' experiences is situated. This study was part of a doctoral research project undertaken in 2016 to explore New Zealand primary school leaders' perceptions and experiences of working to turnaround schools and addressing complex and challenging circumstances within their schools and communities. Using Dewey's theory of experiences, the professional and personal experiences of two female leaders' leading such schools are focused on to understand how their leadership is, in Clandinin and Rosiek (2007) terms, constituted, shaped, expressed, and enacted. The research revealed the professional and personal struggles both women encountered in their journey to turn their schools around, and contributes critical findings to the research focused on women's experiences when turning schools around.

Keywords: women's leadership, school leaders lived experiences, school leadership, statutory intervention, turn around schools 


\section{OVERVIEW}

This paper begins with an insight into my own experiences as a woman leading a school through an intervention process to provide a contextual foundation and position my own experiences as a woman leader within the narrative of the research. In this chapter, I draw from my doctoral research that explored New Zealand state primary [elementary] school principals' [school leaders] perceptions and experiences of Ministry of Education statutory appointees to address issues within their schools. The names of the participants and their school, including my school, were changed to protect the identity of the school leader, and past and present staff, students, and community members (including parents) associated with each school.

An overview of New Zealand's recent historical educational context and the changes introduced following the neoliberal reforms of the later 1980s is provided. This includes the measures the Ministry of Education introduced in the early 1990s to support schools who were struggling to adapt to self-governance. Possible contextual issues surrounding challenging/underperforming schools are discussed. Society's positioning of school leaders is considered and I draw attention to the barriers female education may experience as they seek school leadership positions or promotion. Moving on from this, I consider some factors affecting school leaders as they seek to lead schools through government-sanctioned interventions.

Attention to the experiences of two female school leaders who participated in my doctoral research. Using Dewey's theory of experiences, I examine the professional and personal experiences of these leaders to understand how their leadership is, in Clandinin and Rosiek (2007) terms, constituted, shaped, expressed, and enacted. The findings are shared to reveal some of the professional and personal countervailing pressures the women encountered in their journey to address circumstances in their schools. Continuing from their leadership experiences, I consider how these experiences present a darker side of school leadership that is often unspoken or acknowledged by principals and education authorities. I conclude with a discussion of the key understandings and considerations obtained from my research.

\section{PROLOG}

Mid 2009, I was appointed as the school leader of Porokaiwhiri School, a small full primary school (children aged 5-13 years) situated within a small village in the Waikato region, North Island, New Zealand. Prior to my appointment interview, my initial research into Porokaiwhiri School indicated that there were possibly some Ministry of Education concerns about the school. The contact person listed on the job advertisement was the statutory appointee [limited statutory manager (LSM)], rather than the school board of trustees chairperson or an education consultant. My pre-application queries indicated the LSM was supporting the school to tidy their finances and bookkeeping, and to appoint the incoming leader. The 2008 ERO (Education Review Office) review specified some concerns regarding the learning and achievement of students, but the report indicated these concerns had been resolved and the school received a 3-year review.

Based on my own research and the information supplied by the LSM and the appointment committee at my interview, I did not expect there to be any major issues or concerns that would immediately require my attention. Therefore, I was not prepared for the multiple countervailing pressures and significant issues that were to be the reality of teaching, and leading and managing, Porokaiwhiri School.

Shortly after my commencement, I encountered significant countervailing pressures that included the school's substantial financial debt. My health began to suffer due to long hours spent at work, including numerous weekend and school holidays. A number of times during the school week I would not have time for lunch as I was continually dealing with challenging student and teacher behavior. Student behavior presented substantial long-term pressures, as did their engagement with learning and low levels of academic achievement. The teachers held deficit views of the student, continually engaged in punitive punishment and were disengaged from their teaching. Overall, the school experienced little support from parents and community; student enrolment was declining and there was limited school engagement with external educational agencies and services.

Working in this complex environment, I wondered if other school leaders' experiences of leading high-need schools under statutory intervention were similar.

\section{INTRODUCTION}

While statutory interventions have been enacted in New Zealand since 1994 as a mechanism to "turn a school around," there has been limited research into the performance of statutory intervention processes (see Manion, 2008; Office of the Auditor-General, 2008, 2010; Ministry of Education, 2014a,b; Udahemuka, 2016, 2017a,b). These reviews have continually raised concerns about the consistency of monitoring schools and the lack of transparent intervention processes. The reviews also question the effectiveness and impact of statutory interventions on schools. No studies have been undertake into the long-term impact of a school's intervention. An unpublished Master of Education thesis considers the processes three male New Zealand secondary principals used to turn around their schools (Barker, 2011). However, there is still no research on New Zealand primary school principals, especially those leading small schools under intervention, nor is there New Zealand research into the experiences of women leaders and the personal cost as they seek to turn around underperforming primary schools. With sparse acknowledgment of how statutory interventions affects women leaders' professional and personal lives, it is within these spaces that my research on women principals' experiences is situated. 


\section{Historical Context of New Zealand Education}

The effects of the neo-liberal reforms in New Zealand closely follows those experienced in the United Kingdom and the United States (Thrupp, 2005). By 1987 the centrally controlled New Zealand education system was under review; it did not reflect the ideology of a decentralized system where stateowned enterprises had to compete in the open market and the self-interested individual had the right to choose their service providers (Ranson, 2008). In 1989, the New Zealand government introduced the Education Act 1989 (Kelsey, 1997) and implemented "Tomorrow's Schools" (Lauder et al., 2012). "Tomorrow's School" would be self-managing with a five member elected board of trustees overseeing the governance of a school (New Zealand School Trustees Association, 2010a). It was assumed that each board would "properly reflect the composition of the community" (Codd et al., 1990, p. 18) and that amongst the trustees there would be members skilled in such areas as administration, finance, and policy making. The school board would be able to employ, discipline and fire their staff; manage the school's finances which initially included staff salaries (Lauder et al., 2012). School boards would also maintain the school property and purchase the necessary resources, including staff professional development and training (Kelsey, 1997; New Zealand School Trustees Association, 2010b).

In the years following the implementation of Tomorrow's Schools, the Education Review Office (ERO) and the Ministry of Education began to recognize that some schools and their board of trustees were struggling with the demands of governing and leading self-managing schools effectively and efficiently. Despite being provided with recommendations for improvement by ERO, some of these schools, at all levels throughout the school-the Board of Trustees, leader, and staff, demonstrated that they lacked the capacity, skill, knowledge, and experience to act on these recommendations to improve the situation within the school (Wylie, 2012).

However, while the legislation was in place for the Ministry of Education to provide "safety net interventions" (Thrupp, 2005, p. 47) for struggling schools, there was a reluctance to do so as this went against the ethos of self-governing schools (Wylie, 2013). By the late 1990s, much of the individual school support had shifted away from individual schools to providing school initiatives to clusters of low-performing schools. These initiatives focused on identified needs such as student literacy, student retention, community engagement, and increasing teacher assessment knowledge and understanding (Thrupp, 2005; Wylie, 2009).

While Ministry support for struggling schools had improved, a number of schools with specific contextual concerns still struggled to operate. These contexts included very small schools (with $<50$ students-teacher-leader plus one other teacher schools), schools with $<100$ students, schools serving low socioeconomic areas, schools with high percentages of high-priority students (such as minority or special needs students), and isolated rural schools. All these schools struggled to fulfill and retain teaching positions and maintain a board of trustees (Education Review Office, 1999).

\section{Statutory Intervention in New Zealand Schools}

New Zealand research literature and information obtained from the Ministry of Education indicates one in every 16 New Zealand schools has had an intervention in the past 3 years, with nearly $85 \%$ of these schools serving extremely low-socioeconomic and isolated communities (Redmond, 2017). Policy documents in New Zealand (such as The Education Act of 1989, Part 7A) acknowledge that some struggling schools require more specific and targeted support, and additional resources to improve conditions within the school and address any underpinning governance issues. Current legislation outlines six different levels of statutory intervention to address the identified issues promptly and effectively, with the intention to reduce the likelihood of intensive intervention later on Ministry of Education (2015).

Of the six statutory interventions, my research involved schools placed under the three most complex and lengthy interventions. The Minister for Education publically announces through the New Zealand Government Gazette (the government's official newspaper) (New Zealand Government, n.d) when a school has been placed under one of the following three interventions. The first level of the three interventions is section 78(M) of the Education Act. Section 78(M) involves a limited statutory manager (LSM) working with and alongside the school board of trustees (Ministry of Education, 2015). The LSM holds specific areas of responsibility such as finance, personal, or curriculum matters, while the board of trustees continue to govern all other areas of the school.

The next two levels of intervention are the highest. Section $78(\mathrm{~N})(1-3)$ occurs when a board resigns, or the board has been dissolved by the Minister for Education, or there are not enough people to form a board. Under this legislation, the school board of trustees has been dissolved and a commissioner holds all the roles and responsibilities of the governing board (Ministry of Education, 2015). The terms LSM and commissioner identify the specific role and responsibility, while the collective term for both these roles is "appointee."

The overall aim of any intervention focuses on rebuilding Board of Trustees capabilities and capacity "to perform its functions and exercise its powers in such a way as to ensure that every student at the school is able to attain his or her highest possible standard in educational achievement" (Ministry of Education, 2014b, p. 10). The Minister for Education has the right to intervene at the governance level of the school when there are "reasonable grounds to believe that the operation of the school, or the welfare or educational performance of their students is at risk" (Ministry of Education, 2013). At all times the aim of any intervention is for minimal involvement from the Ministry and for the school to address concerns themselves, returning to being a fully functioning, self-managing board. The final, negative outcome for any school is closure.

It is common for a school under statutory intervention to be removed from the standard 3-yearly ERO review cycle and be placed onto a 1-2 years longitudinal reviews which allows ERO to monitor improvements and sustainability of progress (Education Review Office, 2016). Research into the correlation 
of issues identified in statutory intervention schools and the school's longitudinal report, highlight specific school contextual concerns such as those identified in 1999 remain dominate, and significant internal school challenges around governance (including finances), leadership, and teaching and learning, continue to exist (Manion, 2008).

\section{LEADING TURNAROUND SCHOOLS}

Internationally, governmental identification and sanctioning of underperforming, struggling, declining, failing schools, or schools experiencing challenging circumstances vary (see Berwick, 2015; ETI, 2015; Stotsky and Holzman, 2015a,b; ACARA, 2016; Education Scotland Foghlam Alba, 2017; Ofsted, 2017; Estyn, 2018). For example, within New Zealand, such schools are placed in a statutory intervention that is led by a Ministerial appointee. In the United States of America, "school turnarounds" are common, while in England and Wales, schools are placed in "special circumstances." For ease of reading, I shall use the generic phrase "turnaround" when discussing various government-sanctions intervention processes used to address challenging (including underperforming, struggling, declining, and failing) schools.

The international literature on addressing turnaround schools suggest a two-three timeframe for initiating and sustaining school improvement or intervention program is desirable (Clarke, 2005; Kutash et al., 2010; Leithwood et al., 2010; Pepper et al., 2010; Robinson and Buntrock, 2011; Wallace Foundation, 2013; Liu, 2018). This timeframe is also present within New Zealand's Ministry of Education statutory intervention processes. Critics of the 2-year turnaround timeframe claim there is little evidence to support the sustainability of the changes and people's abilities to maintain the intensive focus postintervention (Southworth, 1998; Smarick, 2010; Lynch, 2012; Stotsky and Holzman, 2015a; Kelly and Clarke, 2016). Authors such as Kowal and Ableidinger (2011), Fairchild and DeMary (2011), and Peck and Reitzug (2014) claim the timeframe to address challenging complex issues is insufficient and most schools require between 3 and 5 years for the issues to be addressed, and up to 7 years for the changes to be fully embedded.

\section{COUNTERVAILING PRESSURES}

Internationally, government school turnaround mandates promote the urgency for school leaders and interventionists to address issues within challenging schools quickly. However, these mandates often present countervailing pressures for those charged with turning around these schools. Theoharis (2007) coined the phrase "countervailing pressures" to describe the push " $n$ " pull school leaders may experience as they seek to implement and embed change. Countervailing pressures may occur from a number of "situations, incidents, issues and people" (Theoharis, 2007, p. 5) and are often present when a leader wants to lead the school in one direction, but someone, or something is hindering, diverting or stopping the process. In this sense, countervailing pressures may enable or hinder the leaders work (Møller, 2012) and be present within the very "structures, functions, routines, and roles" (Spillane, 2005, p. 143) of school leadership. Other times a school leader may need to work against the directions of education authorities, especially when the leader perceives this is not in the best interest of the students or school, by actively or subtly challenging the status quo or slowing down the process of change. In this sense, leaders can be both the "catalyst [of change] and the agent of support" (Hallinger and Heck, 2011, p. 4).

Countervailing pressures associated with cultural (Cavanagh et al., 2012), socio-economic (Ahumada et al., 2016), societal and political considerations and issues (Goldstein and Woodhouse, 2000) can be school stressors, affecting some schools to greater or lesser extent than others (Reynolds, 1995; Tomlinson, 1997; Nicolaidou and Ainscow, 2005; Muijs, 2014). School leaders may also experience countervailing pressures based on societal assumptions of who a leader is and this may include assumptions based on leaders inherited characteristics such as about gender, culture, and race. Internal school countervailing pressures may exist around peoples' resistance to change and pressure of timeboth within and from the school and community for example.

Each school has its own set of unique set of problems and challenges (Dinham et al., 2011; Duke, 2014). Leithwood et al. (2010) argue the right combination of "contextual, compositional, cyclical, contingent, and conditional factors" ( $p$. 39) present schools with a "perfect storm." School leaders undertaking turnaround work are "sensitive to the unique challenging circumstances faced by [their] school" (Jang et al., 2008, p. 225). School leaders will adjust their leadership style and dispositions to best match the current situational context of the school (Morris, 2014), at that particular time (Fairchild and DeMary, 2011; Papa and English, 2011; Bouchamma, 2012; Notman, 2015), and "stage of the school's development" (Harris, 2002, p. 17). Yet by doing so, a school leader may experience some unexpected countervailing pressures. Overtime, continual countervailing pressures may adversely affect principals' health and well-being. I shall address some possible countervailing pressures for leaders of turnaround schools in the following sections.

\section{Societal Countervailing Perceptions}

School leadership is complex, unpredictable, and laced with multiple countervailing pressures that require resolution on a daily basis. Each school, its context, circumstances and situation are unique. Thus, each school may present unique challenges or countervailing pressures for school leaders. Leaders of struggling/challenging schools face immense pressure to address issues swiftly, particularly those affecting students (Moctezuma, 2017). New Zealand's Ministry of Education (2008) state school leaders must have the "personal and professional qualities, knowledge, and leadership skills" (p. 8) required to turn around schools. Educational leadership literature indicates school leaders seeking to turn around schools must have the dispositions and be committed and passionate about working in schools (Nicolaidou, 2005; Medina et al., 2014). Furthermore, turnaround leaders should have the skill and authority to implement change (Kowal and Ableidinger, 2011). While Lochmiller and Chesnut (2017) 
acknowledge and promote the importance for leaders to have high levels of mental focus and emotional energy to manage their own emotional state.

\section{Heroic or Savior Leaders}

Educational leaders who lead schools during government sanctioned intervention processes are often positioned as "heroic," "charismatic," or "white knight" leaders who seek to address students' low academic performance by changing the school climate and culture (Goddard, 2003; Spillane, 2005; Starr, 2014; Mann et al., 2017). The discourses around these leaders suggest schools and communities want strong (male) leaders in times of crisis or significant change (Harris, 2003; Ainscow et al., 2005; Caldwell et al., 2012; Shulman and Sullivan, 2015; Holmes, 2017). These discourses, while affirming societies typical hierarchical positioning of school leaders as authoritarians with who yield power and control (Abrahamsen and Aas, 2016; Holmes, 2017), negatively affect the likelihood of women leaders being appointed to undertake this work.

An alternative to the heroic and charismatic discourses is the "savior" where leaders (often women) have "sacrificed everything for the school, including [their] personal life" (Møller, 2012, p. 455). Within school turnaround literature, savior leaders are presented as dedicating their life's work, including personal finances, to their school. Savior leaders challenge policies that disadvantage disengaged students and lead with tough- and softlove leadership (Berkovich and Grinshtain, 2018). These leaders draw on community good will and engagement to address areas of concerns such as the physical condition of the school. By contrast (Thomson, 2009), refutes the savior view suggesting some turnaround leaders may be driven more by "ego than altruistic work" (p. 58).

Heroic and savior discourses disregard the nature of schools and the relational practices necessary to bring about change. In contrast to the heroic, charismatic and savior leadership discourses, glass elevator theory considers the seemingly accelerated promotions male leaders experience while glass ceilings and cliff theories highlight the barriers women experience while seeking leadership positions or promotion.

\section{Glass Elevators, Ceilings, and Cliffs}

In contrast to the difficulty women report in obtaining leadership positions, males report experiencing little/no difficulty gaining leadership appointments or promotions. Researchers, such as Eagly (2005) and Weiner and Burton (2016) speculate some male leaders are being appointed through a process of "cherry picking" (whereby the exiting/retiring male principal picks their successor) or they experience the "glass elevator" affect (leadership pathway is smoother than that experienced by females with similar skills, experience, and qualifications). Concerns are also raised that males obtain positions through the "old-boys" network whereby experienced male leaders encourage, groom, mentor, and "sponsor" younger males to apply for leadership positions (Shakeshaft et al., 2007; Torrance et al., 2017; Weiner and Burton, 2017).

A number of researchers (for example Eagly and Sczesny, 2009; Thomson, 2009; Cook and Glass, 2013; Weiner and Burton,
2016; Wyland, 2016) note many women leaders continue to "face challenges in achieving legitimacy" (Eagly, 2005, p. 461) due to gender stereo-typical views, prejudicial disadvantages and discrimination within and outside the education profession (Eagly and Carli, 2003). As a result, women leaders are more likely to experience the invisible, but very real "glass ceiling" affect when applying for promotion, regardless of their experience, competency, and academic qualifications (Eagly and Carli, 2003; Cook and Glass, 2013; Franquiz, 2013; Bruckmüller et al., 2014; Glass and Cook, 2016).

Gardiner et al. (2000), Grogan (2002), and Shakeshaft et al. (2007) suggest many women leaders do not receive the same level of support, grooming, mentorship, or sponsorship that their male counterparts receive, thus preserving the glass ceiling. These authors draw attention to the importance of same "race, gender, and culture" (Shakeshaft et al., 2007, p. 112) mentors in helping women leaders to "see" themselves in leadership roles. Mentors can help women to overcome perceived barriers to promotion, and entry "hidden" institutional knowledge and understandings (Grogan, 2002). Further, mentors can support women to access development of professional networks and professional development (Gardiner et al., 2000; Shakeshaft et al., 2007; Collins, 2015; Torrance et al., 2017; Robinson et al., 2019).

Leadership research also indicates women leaders are increasingly appointed to glass cliff positions (Haslam and Ryan, 2008; Ryan and Haslam, 2009; Bruckmüller and Branscombe, 2010; Ryan et al., 2011; Weiner and Burton, 2016). Glass cliff theory highlights the likelihood of women being appointed to top leadership positions in organizations that are struggling, atrisk of failing or in a crisis than males (Ryan and Haslam, 2005). One posited theory suggest this move signals to stakeholders that the situation is being addressed, especially if the current situation can be linked to previous [male] leaders (Bruckmüller and Branscombe, 2010; Bruckmüller et al., 2014; Kulich et al., 2015). Other theories suggest women "soft" authentic attributes such as high emotional intelligence and relational skills (Glass and Cook, 2016) promote alternative ways of leading and encourage inclusive, cohesive, and supportive work environments (Ryan et al., 2011; Kulich et al., 2015) required in organizations undergoing turnaround processes.

Regardless of the rationale, women leaders experience a double-bind-utilize authoritative leadership styles and be labeled as "tough" or be authentic to themselves and be perceived as "lacking" leadership skills, especially if the organization continues to fail (Eagly, 2005; Shakeshaft et al., 2007; Glass and Cook, 2016; Weiner and Burton, 2017). As such, glass cliff positions be hostile and highly dangerous for women leaders and society in terms of future leadership positions and overall negative generalizations of gender stereotyping.

The limitations of the heroic and savior discourses, as well as the glass elevators, ceiling, and cliff theories, is the premise that leaders fit neatly into these various categories. A number of school leaders' public narratives continue to support these assumptions as these stories are "positioned and presented ... within a specific moment in historical time and situated in expectations" about the audience (Møller, 2012, p. 453). These narratives enable leaders to construct and maintain 
their "public self" and people's perceptions of their leadership skills, knowledge, and ability (Møller, 2012). Yet, hidden within these leadership discourses and narratives are the real stories, identity, and experiences of school leaders (Shakeshaft et al., 2007; Linn, 2011). School leaders seldom discuss their personal sense of purpose, their fallacies and courage, or the barriers and difficult moments they have experienced while leading a school. Consequently, educationalists and society have little knowledge of how leading challenging schools such as those under government intervention, affect principals' professional and personal lives.

\section{Loneliness and Isolation}

School leaders working in turnaround schools are under extreme daily pressures (Jongewaard, 2006). Within educational research literature, concerns of leader isolation, alienation, and loneliness are acknowledged in relation to the experiences of novice school leaders. Novice school leaders are more likely to experience a sense of loneliness and isolation (Piggot-Irvine, 2004; Patuawa, 2007; Northfield et al., 2011; Starr, 2011; Northfield, 2014). Educational leadership researchers (for example Herlihy and Herlihy, 1980; Northfield et al., 2006; Starr, 2011; Northfield, 2014) found novice, transferring and women school leaders are more likely to experience isolation than male leaders who have been in their current school for 3 years or more. It is therefore probable that positional isolation (Wesson, 1998; Lindorff, 2001; Raymond, 2007; Kelchtermans et al., 2011; Spillane and Lee, 2014; Waytz et al., 2015; Liljenberg and Andersson, 2019) is associated with a lack of professional networks and professional socialization (Crow, 2006; Robinson et al., 2019) as much as it is able establishing oneself as the leader of the school. School leaders in small and/or rural schools are likely to experience geographic and social isolation (Starr and White, 2008; Halsey, 2011; Lock et al., 2012; Wildy and Clarke, 2012; Sayce and Lavery, 2013; Cornish and Jenkins, 2015) where the physical distance between schools and communities make it difficult for leaders to establish professional and social relationships outside of their community. It is possible then, that women leaders leading isolated, rural schools may experience a greater sense of loneliness and isolation than males in similar contexts. Some women leaders also note additional cultural and societal pressures of "constantly negotiating their coexisting roles" as professional/wife/mother (Torrance et al., 2017, p. 29). While others indicate the level of support and encouragement they receive from their families, enable them to obtain and retain school leadership positions (Robinson et al., 2019).

Principals may also experience a sense of isolation when working educational authorities. For example the three male secondary principals involved in Barker (2011) research noted "feelings of isolation, frustration and anger, abandonment and a lack of trust" (p. 98) from the Ministry of Education, school board of trustees and ERO, as they sought to understand how their respective schools had declined. Additionally, like many school leaders, these principals noted feelings of isolation and stress due to the long hours they worked to address internal school issues. Stephenson and Bauer (2010) state, "isolation significantly impacts physical and emotional burnout" (p. 14) affecting a school leader's quality of work life and can have long-lasting negative effects on the leaders health and well-being.

School leader networks and being involved in ongoing PLD may provide opportunities for professional and social networks to develop. Hadfield and Jopling (2012) state most inter-school networks "arise from informal head teach [principal/school leader] groups" (p. 115). These groups enable reciprocity of knowledge and information, share vision and educational goals for the district, and social relationships to develop (Friedkin and Slater, 1994; Billett et al., 2007; Chapman, 2008; Dhillon, 2013). Other benefits may include inter-school teacher and leader visits, collaborative professional development, access to previously unknown sources of support for families and new places for students to visit. Other benefits include the development of social-support groups amongst school leaders and having someone to discuss school and/or leadership concerns with away from the locale of the school (Siciliano, 2015). Informal networks, such as those developed outside of education can also help women leaders connect with others, thus increasing their chances of having "insider knowledge" about forthcoming positions or internal school issues (Shakeshaft et al., 2007; Robinson et al., 2019).

However, Kelchtermans et al. (2011) warn that feelings of isolation, alienation, and loneliness may intensify after professional gatherings and "ultimately result in increased loneliness" (p. 102) especially if the school leader is returning to a challenging situation. As a number of women leaders report feeling marginalized and isolated by their professional male counterparts at leadership meetings, attending conferences may further enhance their sense of isolation (Gardiner et al., 2000; Collins, 2015; Torrance et al., 2017). Educational research indicates it is particularly important for women leaders to establish their network of trusted friends, colleagues, and mentors (Gardiner et al., 2000; Robinson et al., 2019). This network can provide understanding, knowledge and awareness of both the overt and covert aspects of their role and provide them with support, encouragement, guidance, and advice. Networks can help reduce feelings of professional and social loneliness and isolation and stress (Dussault and Barnett, 1996; Gupton and Del Rosario, 1998; Piggot-Irvine, 2004; Patuawa, 2007).

\section{PRINCIPAL WELL-BEING}

Redding and Morando Rhim (2014) claim there is a cost involved for the school leader when leading a challenging school such as one under a statutory intervention. Often this cost is considered in terms of hours worked and workload (Oplatka, 2017; Eacott, 2020). More recently, research and surveys on the hidden "cost" on school leaders' health and wellbeing, particularly in relation to their workload, is increasing (for example Hodgen and Wylie, 2005; Howard and Mallory, 2008; Phillips and Sen, 2011; Riley and Langan-Fox, 2013; Riley, 2014, 2015, 2017; Beausaert et al., 2016). Yet, school leaders themselves do not speak out for fear of being found wanting, or being judged as not coping nor suitable for a school leader's role (Sachs and Blackmore, 1998; Beatty, 2000; Leithwood and Beatty, 2008; Blackmore, 2013). 
Leading and managing a school is emotionally charged work. Leaders are continually engaging with others and must walk an "emotional tightrope" which includes "controlling emotions" in some very challenging and complex situations (Timms et al., 2006, p. 344) in order to maintain their professionalism and the emotions of others (Sachs and Blackmore, 1998; Pratt-Adams and Maguire, 2009; Mills and Niesche, 2014). However, Grayson and Alvarez (2008), Phillips and Sen (2011), and Timms et al. (2006) warn the long-term emotional dissonance of continuously disregarding personal feelings and well-being can have serious physiological, psychological, and psychosocial implications for a leader. These implications include depression, alcoholism, and health problems (Dussault and Thibodeau, 1996). More concerning, if a school leader becomes burnout, they may experience heightened feelings of emotional fatigue, mental, and physical exhaustion and hopelessness which is a precursor of depression and suicidal behavior (Gold, 1984; Oplatka, 2002; Hadley and MacLeod, 2010; Segal et al., 2017). Their leadership style and management of the school may become "unhealthy and dysfunctional" (Kelehear, 2004, p. 31), compounding any issues within the school. Leaders then become "caught in a double bind" (Herlihy and Herlihy, 1980, p. 8) of either wanting to "fight" or "flight" various "situations, incidents, issues and people" (Theoharis, 2007, p. 5).

Emotions are not something "to be controlled and played down” (Kelchtermans et al., 2011, p. 95). School leaders positive thoughts, emotions, and believes about their school may be the very thing that keeps them returning to their school day after day, regardless of the tough, difficult, or challenging moments and countervailing pressures. When school leaders feel positive about their school and their role, and when they receive appropriate and individualized support, emotional exhaustion decreases and selfefficacy increases (Beausaert et al., 2016) and the school culture and overall health and well-being, benefits.

\section{METHODOLOGY}

A narrative inquiry underpinned my ontological and epistemological positioning for this research. I belief we independently gain knowledge and understanding of our world through experiences. Yet, it is through our interactions with others, that our understanding and knowledge is enhanced, developed, and extended. We then apply this new, existing knowledge, to our future interactions and experiences (Dewey, 1938). Dewey (1938) states "all human experience is ultimately social: that it involves contact and communication" (p. 38). He believes with "every experience enacted and undergone" (Dewey, 1938, p. 35), we are changed in some way; we are not the person who first entered into the experience as the person who emerges from the experience.

Barkuizen et al. (2014) suggests the main strength of narrative inquiry is the use of people's stories to "make sense of their experiences ... it is important to understand phenomena from the perspectives of those who experience them" (p. 2). These stories provide differing perspectives of an event and "often uncover issues that had not previously been visible" (Barkuizen et al., 2014, p. 5). It was through the gathering of the participant leaders' stories that I sought to make visible the experiences of two women New Zealand primary school leaders as they led their school through the statutory intervention. It was important I understood the context of the stories being shared, how each leader positioned their social and cultural realities, and how these may have influenced or affected their leadership experiences. I also needed to understand that for each leader, every time they revisited and retold their experiences, their memory and views of particular events might change and evolve as they "explore[d] memories and [gained] deeper understanding" of their experiences (Polkinghorne 2007, in Clandinin and Murphy, 2007, p. 644), and their understanding of these experiences may have also changed with time. It is through the leaders' narratives that I will understand how their leadership of a school under statutory intervention is, in Clandinin and Rosiek (2007) terms, constituted, shaped, and expressed.

\section{Purposeful Sampling}

The participant leaders in my research were identified through the process of purposeful sampling (Patton, 2002; Ritchie et al., 2014). The selection criteria was limited to New Zealand state primary school leaders who had led their school through a statutory intervention. The school type [either contributing (Years 1-6) or full-primary (years 1-8)], size (under 150 students), and socioeconomic status of potential schools was important (but not limited to). These criteria purposefully narrowed the number of potential primary schools to 803 , of which 264 schools were serving low-socioeconomic communities. From this pool, 38 schools met the following criteria: the school had to have recently been, or was still, under statutory intervention, with the school leader leading the school for some or all of this process. I purposefully selected schools located outside of my home region, and I sought gender-balance amongst the participants. The schools were identified through public-access websites such as the New Zealand Government Gazette, the official newspaper of the government. The Gazette publishes the names of schools that have entered into, changed between, or been removed from, statutory intervention (New Zealand Government, n.d). Ministry of Education's Te Kete Ipurangi (TKI) site [a site for schools and teachers to obtain information, resources and curriculum material (Ministry of Education, n.d)] was also accessed. This site contains all pertinent information about school location, size (number, year level, and ethnicity of students), socioeconomics, and school leader's name.

Accounting for recent changes in leadership, I had a potential research pool of 22 leaders as prospective "information-rich" (Patton, 2002, p. 46) participants with recent knowledge and experience of statutory interventions. From this list, I randomly phoned the identified schools to speak to the school leader. It was important for the success of this research that I authentically connect with participants if I was to hear their lived experiences, their realities, of leading a high-needs school through a statutory intervention (Polkinghorne, 1995; Bush, 2012; Dimmock and Lam, 2012; Josselson, 2013; Patton, 2015). To achieve this, I briefly acknowledged my insider-research position by sharing 
some of my professional experiences of leading a school through a statutory intervention (Clandinin and Rosiek, 2007; Pelias, 2011; Bold, 2012; Busher and James, 2012; Munn-Giddings, 2012). I wanted school leaders to know that I too had experienced situations and events that may have been similar to what they had recently experienced. I wanted them to be fully aware that my research traversed sensitive territory. I was also aware that for some leaders, this might be the first time they had the opportunity to share their professional and personal experiences of leading a school through a statutory intervention, without worrying about professional or personal consequences (Josselson, 2013). Of the six leaders who agreed to participate, three withdraw over the research period for professional or personal reasons. This left three participants, one male and two womens.

\section{Data Gathering and Analysis}

Each school leader was interviewed three times over a New Zealand school year. Each interview lasted between 60 and 90 min with several interviews lasting longer than this as the participants raised a number of other topics including leadership issues and general school, staffing, finances, and curriculum concerns. In these instances, my position as an insider-researcher appeared to have shifted to one of a colleague discussing leadership issues. I was very cognizant that each participant may have needed the opportunity to talk to a "stranger on the train" (Josselson, 2013). A semi-structured interview guide was used for each interview (Sparrowe, 2005; Kvale, 2007; Barkuizen et al., 2014; Patton, 2015). Each interview was digitally recorded and field notes were made following each interview. I transcribed each interview verbatim and the transcript was returned to each participant for member checking (Henn et al., 2009; Knox and Burkard, 2009; Dimmock and Lam, 2012; Josselson, 2013; Patton, 2015).

Over multiple readings of the transcripts, overarching themes began to emerge. Code/theme books where allocated to each participant. Significant information were grouped and recorded verbatim, margin notations indicated the original transcript and page (or instance 2:7 meant interview 2, page 7). Some information such as a comment about the statutory appointee was coded to multiple themes (for example Appointee, Challenges, Impact on Principal, and Knowledge about SI). At this stage of data analysis, the coding was an open process in that the data was coded "in everyway possible" (Glaser, 1978, p. 56). Thus the books were "collection points for significant data" (Lewins et al., 2010). (Glaser, 1978) suggests this type of coding is inductive and enables a variety of themes to emerge. Repeated themes were continually refined with several hierarchies of themes and subthemes developed, refined, and discarded along the way (Ryan and Bernard, 2003; Braun and Clarke, 2006). This process allowed me to interact with, and move "inward and outward, backwards and forward" (Clandinin and Connelly, 2000 , p. 50) between the text and the principals experiences. The final process of data analysis revolved around the continuity of time (Dewey, 1938; Clandinin and Connelly, 2000). Using continuity of time enabled me to present the hierarchy of themes as chronological and sequenced events (Ollerenshaw and Creswell, 2002; Coulter, 2009).

\section{Limitations}

This study is not without limitations. Firstly, the scarcity of New Zealand literature on school leadership during challenging circumstances such as a statutory intervention has resulted in the wide use of international literature. Therefore, transference of international situations and contexts to the New Zealand educational context is not always manageable. There are limitations present within the wider research and the findings presented in this chapter. There may be limitations in applying these findings to a larger cohort of New Zealand school leaders, or to leaders leading schools in other education systems.

Secondly, the small sample size, and the research focus specifically on school leaders leading a small New Zealand state primary school under challenging conditions, makes it inappropriate to generalize these findings to other school leaders. Lastly, my interest in school leaders' experiences of statutory intervention originates from my own personal experiences of leading during such circumstances. Therefore, when interviewing, analyzing, and presenting the findings and discussion, I am conscious of my insider-research positioning and possible biases toward particular ideas. This was addressed through member checks and supervisors' feedback.

\section{THE NEW ZEALAND SCHOOL LEADERS AND THEIR SCHOOLS' CONTEXTS}

The two women primary school leaders who participated in my research had been leading and managing their respective schools through 12-18 months of statutory intervention before I interviewed them. Susan, Matai School and a declining situation.

\section{Susan and Matai School: A Declining Situation}

Susan was a New Zealand trained teacher with 15+ years' experience prior to accepting the senior leadership position at Matai School. At the time of Susan's interview, Matai School was located in a rural, semi-isolated farming village. The socioeconomic rating of the school of 8 (with 10 being the most affluent communities, 1 being extremely low-socioeconomic rating). Matai School was classified as a full-primary (Years 18), but often "lost" Year 7\&8 (aged 11-13) students to boarding school (Years 7-13) or area schools (Years 1-13).

Upon arriving at Matai School, Susan noted the school roll had decreased from an expected 27 students (at the time of her interview) to 12 students. She noted issues with student behavior and social skills, non-engagement with learning, and low student achievement. For the next 5 years, Susan worked to stabilize the school, addressing multiple issues along the way, and re-engaging the community with the school. She was proud of the progress and achievement of Matai School and the roll had increased to 47 students. This was just three students shy of Matai School employing a third full-time, Ministry-funded classroom teacher. Susan felt things were coming together nicely when community issues began affecting Matai School.

On reflection, Susan believed relationships amongst community members had been volatile for about a year. She 
noted various community members falling out with one-another, affecting the school as parents withdraw their support not only from the community, but the school as well by withdrawing their children. Notably, Susan felt the local parent-teacher association (PTA) had begun to overstep their role as they started voicing their views on how the school should be lead and governed, including what learning the students should be doing and when. An incident occurred when the board of trustees sought a new board member. Susan shared the PTA had encouraged the newly appointed member to apply for the position, in the hope that the group would obtain more detailed information about the running and governance of the school. More importantly, the new member disclosed to the board that the PTA wanted to run the school, and wanted Susan to resign. When the new member did not agree with this plan, they lost the support of the PTA members, and later resigned from the board.

With a declining school roll, the board was unable to fill vacant seats (Boards consist of five elected parents/community members). In consultation with Susan, the board decided to contact the Ministry of Education for assistance. Susan and the board believed the fastest way of obtaining support for Matai School was for the elected board members to resign, effectively triggering a Section $78(n-3)$ (school operating without a governing board of trustees). The Ministry of Education appointed a commissioner (a person who holds the full duties and responsibilities of the board) to govern the school.

\section{Grace and Pohutukawa School; Stepping Into the Situation}

Pohutukawa School was located in a small rural town. The primary industry was farming with supporting industries; a number of people commuted to a neighboring larger town, or the region's city, for work. Pohutukawa School was a full-primary school with a social-economic rating of 3 and historically "lost" some Year 7\&8 students to the intermediate school (Middle school) in the neighboring town. Other students were "poached" by out-of-zone schools who provided free transportation. The school roll consistently sat between 100 and 120 students.

The Minister for Education appointed a commissioner to govern Pohutukawa School under Section 78n(1-2)-concerns for the governance of the school and student well-being and academic achievement following the previous leader's resignation and then the full school board of trustees. In the months prior to Grace's appointment, Pohutukawa School had two consecutive interim school leaders.

Grace is a New Zealand trained teacher with over 20 years' experience. Pohutukawa School was her third senior leadership position. Grace has always moved between classroom teaching, senior management, and school leadership positions depending on the needs of her family, or her desire to upskill or work in different sized schools. Immediately prior to her appointment at Pohutukawa School, Grace had worked as a deputy school leader in a small school that had been under a statutory interventionsection $78(\mathrm{~m})$ (limited statutory manager working alongside the school board). In total, Grace had $\sim 7$ years of school leadership experience.
When I interviewed Grace, she had been a professional leader of Pohutukawa School for about 18 months. She was unaware of the issues surrounding the departure of the previous school leader or school board. Prior to her appointment, Grace knew the school was having trouble and was currently under statutory intervention, as the commissioner interviewed Grace for the leadership position. She applied for the position as she felt she had the experience and the capability to lead the school out of this situation. Grace vividly recalls driving into the region for her appointment interview. She felt an instant connection with the region as her family whakapapa back to the area [whanau tangata (family ties) to the land]. She remembers driving past the maunga (mountain), a significant landmark in the region, and telling her husband "that's my mountain." She stated she had often heard other people identifying or connecting with their maunga-both culturally and spiritually, but had never understood what they were meaning. Grace understood this immediately upon her connection with "her" maunga.

\section{CONTEXTUAL COUNTERVAILING PRESSURES}

Both Susan's and Grace's stories highlight significant commonalities and differences of the professional and personal pressures they met as they worked to address the issues within their respective schools. Throughout Susan and Grace's leadership of their schools, they experienced countervailing pressures from a number of "situations, incidents, issues, and people" (Theoharis, 2007, p. 5). For example, while they acknowledged the urgency in addressing the issues, at different stages of the statutory intervention, they found themselves challenged and significantly impacted by these issues and various people in different ways (Redding and Morando Rhim, 2014). At the same time, there were incidents when the leaders actively or subtly challenged the status quo or the statutory appointee. In this sense, Susan and Grace were both the "catalyst [of change] and the agent of support" (Hallinger and Heck, 2011, p. 4). In the following sections, I focus on two significant countervailing pressures the leaders experienced.

\section{Isolation and Lack of Support}

A significant emotion felt by both leaders was their feeling of isolation and a lack of support from educational agencies and authorities. In Susan's circumstances, her network of fellow leaders was geographically determined and she seldom attended local or regional school leaders meetings or PLD (professional learning development) due to travel distances or teaching commitments. Although she had been Matai School's professional leader for 9 years, this was still her first senior leadership position. She had no experience being a school leader in other areas of her region or within New Zealand. While Susan had participated in a mentoring program for first-time school leaders, she had not maintained connect with this group of school leaders or her mentor.

I've received very little professional support over the past 7-9 years. There were always petty things like bus zones and routes 
causing division. As a school, we were never invited anywhere and no one came to visit us. Other local principals are all male, they socialize together, both professionally and personally. I'm not included - I don't get invited to principal's events or end-ofterm drinks.

Susan described the first year of Matai School's intervention as "horrific," "difficult year," "turmoil" and "hell." She felt "threatened," "frightened," and "worthless" at various times throughout that year by the actions or words of the male statutory appointee. For example, during a community meeting about a proposed school camp, some parents were pushing for a particular place that was too expensive for some families. When the staff raised this issue, the appointee informed them, "You'll do as we say; I don't care what you think."

Susan felt she was in a situation with no clear nor easy way out. While she refused to "bow to the demands" and pressures of various parent groups, Susan felt helplessness and powerless doing so with the statutory appointee. In these instances, and to ensure things ran smoothly, Susan commented she often "had to suck it up and put on her big girl knickers [panties/underwear], suck it up" and just get on with things.

The people she relied upon most, were her parents, who were elderly, but she felt this "if I didn't have family and friends here, I definitely wouldn't be here. It was that critical." Above all, Susan felt conflicted in her role of being the "leader" and she struggled to navigate the boundary between this role and being friends with the teachers and parents of Matai School in a rural community. She voiced her frustration at being socially isolated

I feel very isolated; it's hard because you're not meant to be friends with people in the community, you're here in a professional role. Theoretically, you're meant to be professional toward them, and available, but not friendly.

You're always mindful of what you are saying and who is connected with whom in the community. It's really hard. Are we meant to be socially isolated because of our role and position within the community, or do you become involved with the community, but then you're too close. It's hard. ... You've got to live, you've got to have friends and socialize, but where's the line? I don't know. I don't have a husband/partner or children to help bridge that gap.

Grace, on the other hand, while having moved to a new region to lead Pohutukawa School, had her immediate family and she came from a family of educators, some of whom were also school leaders or educational advisors. She also maintained her connections with previous colleagues. However, taking on the leadership of a school in a new region was not easy. Grace recalls:

Had only been here a couple of weeks. One neighboring [male] school leader came to visit-this person assumed I was a first-time principal (FTP). They said "well, you'll be a FTP, so I'll be able to tell you what to do". That was their first strike; they kept talking over me when I told them I was an experienced leader. I didn't give them benefit of getting three strikes. I walked them out to their car. Never trusted that person again.
Following this incident and several others with other male school leaders at meetings, Grace was weary of discussing school issues. She felt protective toward the community and did not want any negative information to be used against her, the school and the community.

I am very guarded when talking about the school with neighboring leaders. They've taken students from Pohutukawa School before; I don't need to give them any more ammunition. I don't divulge a lot of what goes on in the school and community. You need a certain level of professional from people and if you do not see or hear that from them, then....

I guess, I don't know, when you come in [as an outsider] you uncover a whole lot of stuff. The reality verses what you are told about the school and its issues are usually poles apart because you're on the ground and people begin to trust you, so they starting sharing some horrific stories of past hurts. Other people don't need to know those stories; those stories can be more damning to a community than good.

Philosophically, Grace felt isolated. She shared it was hard introducing new ideas [such as play-based learning] into a school when no other local school was moving that way.

At times, it would be easier to just flag [stop] all that we're doing and return to the tradition ways. It would be easier, but not necessarily the right or best thing for the kids at this schools. That's my problem [laughing] —nah, I couldn't go back.

As the school was under section $78 \mathrm{~m}(3)$ and therefore governed by a statutory appointee, Grace did not have a local contact person who could help and support her to settle into the school prior to the school opening for instruction. Unexpectedly she felt relationally isolated from the statutory appointee.

Having an appointee living three hours away is extremely challenging; it is extraordinarily difficult to maintain a working relationship over that distance and only seeing someone every three-four weeks. You do not have on-the-ground support, so effectively, you're also doing a lot of the daily governance work that the appointee should be doing. You do not have support on the spot and when things goes pear-shaped, you need that immediate, physical support.

With no school board of trustees, there was no-one else to deal with the local governance issues of managing a school, such as signing off bus routes, accounts, or numerous other weekly tasks which the board attend too, nor was there anyone to ensure the gardens were weeded and the grounds tidy, for instance. Grace questioned

When you do not have on-the-ground support, then who does this work?

I don't have that! You're it! You're being and doing all! ... adds to the stress when you don't have that support right on the spot. It's inherently wrong! But you do it for the kids, we are here for the kids. 
Both Susan's and Grace's feelings of isolation were deepened by the lack of professional support and trust they had in others. The women draw attention to the "old-boys network" operating within their school districts. They felt a number of inter-school decisions were made prior to official meetings, either over drinks or on the sports field or golf course. They felt that even if they had received invitations to social events, the nature of the men's network positioned them as "outsiders" within their own profession. Grace noted the male leaders would go on golfing trips to wineries but female leaders were never included in these trips. Grace had also heard that a group of male leaders had an annual game of rugby against another region; again, females, including wives/partners were not included.

The principals' dual roles of being a professional within a small community, and being a community member, compounded their sense of professional and social isolation. Susan in particular, found it difficult to transverse this duality, whereas Grace, having shifted with her family a number of times prior to arriving at Pohutukawa community, had the support of her immediate family and a large supportive network outside the region.

\section{Health and Well-Being}

Both Susan and Grace voiced their concerns surrounding school leader's health and well-being. At the same time, they both acknowledged they seldom discussed their own health and wellbeing, particularly in relation to their work, with colleagues for fear of being found wanting, or being judged as not coping nor suitable for a school leader's role.

While Susan was an experienced school leader, Matai School was still her first school leadership position and only her second teaching position. It is likely Susan's struggles with the male statutory appointee and her continual fight to retain her position and protect her school, had exhausted her personal reserves and she experienced some serious health issues. She reported these concerns included weight gain, decreased mobility and insomnia. She also noted feeling anxious as soon as she approached Matai School each morning and this feeling lasted until she returned home in the evening. On top of these health issues, Susan experienced several episodes where she felt things were just too difficult.

\footnotetext{
I became depressed - I really fought that. But it wasn't like depressed and give up. I became a lot angrier last year, fighting. I think if I hadn't done that, I wouldn't have been here. There were two points last year where I would have committed suicide as I got to the stage where I thought that was the best option. Mentally, it's been huge. I need to get that confidence back. I need to pull that back in somehow.
}

Both times Susan considered ways to take her own life, but it was her thoughts about the effect this would have on her elderly parents, that stopped her. She said that with help of her GP and high dosages of vitamins D, she fought her depression and suicidal thoughts. She believed that without the anger over continually fighting for her job and for Matai School, she would not have survived.
Her final comments regarding her experiences of leading a school under statutory intervention were

I made it! But at times, life was unbearable! ... would've committed suicide. I was at the point where I thought that was the best option.

I loved this school; I have loved it with a passion. But I have fallen out of love. I am re-establishing my relationship with this school. Life is becoming brighter again.

In contrast to Susan, Grace's health was stable. She ensured she had systems in place to maintain her emotional safety, especially with any difficulties she faced at work, or the troubling stories students, parents and teachers at Pohutukawa School shared with her. Grace contributed this to having worked in challenging schools before as well as having the support of her husband and extended family "My husband is my greatest support. He is very good at listening [laughing]." She also ensure she spent her weekends with her family, often leaving the region during school breaks to visit family and friends. Grace shared that she was quite self-sufficient, saying

It's about mental health, it's about emotional safety. You have to be able to say, right, there is my emotional line and I can leave that [person's story] there, the crisis is theirs; do not get emotionally involved.

I've grown with this school. I've grown, changed and moved in my thinking, actions and philosophy. I've learnt at this school how to keep emotionally out of that space and be able to listen and maintain integrity and that relationship.

\section{DISCUSSION}

This study focused on the perceptions of two women primary school leaders and their experiences of leading schools through a statutory intervention. Their stories are located during a time when each leader was experiencing multiple complex and challenging "situations, incidents, issues and people" (Theoharis, 2007, p. 5). The findings highlight Susan and Grace's perceptions of isolation, despite having a Ministry of Education statutory appointee working with them. In such circumstances, it might be presumptuous to believe they felt a higher level of support and guidance. That they did not, suggests other issues were present.

Issues of experienced school leader's professional isolation largely appear to be absent in the educational leadership literature (Dussault and Thibodeau, 1996; Bauer and Brazer, 2013; Bauer and Silver, 2018; Bauer et al., 2019). This absence is especially profound in international school turnaround literature. The findings from this research highlight the complex relationship between human existence/the innate need for survival and the unrelenting pressures and expectations felt within their professional roles. For both school leaders, their sense of professional isolation was intertwined with other variables that "affect[ed] the quality of [their] work," and influenced how they "process[ed] and respon[ed]" (Bauer and Brazer, 2013, p. 154) to situations within their work environment. In particular, Bauer and Brazer (2013) suggest variables such as stress, "role 
ambiguity, conflict and overload" (p. 156) can significantly affect school leader's sense of isolation.

While it is acknowledged that school leaders generally work in isolation, Dussault and Thibodeau (1996) and Bauer et al. (2019) suggest professional isolation is deeper than this. Professional isolation has been defined as an "emotional response to one's [work] experiences" (Bauer et al., 2019, p. 386). A school leader's profound sense of isolation not only affects their job satisfaction and self-efficacy, but has serious health and well-being implications such as depression, burnout (physical, cognitive, and emotional) (Dussault and Thibodeau, 1996; Izgar, 2009; Stephenson and Bauer, 2010; Federici and Skaalvik, 2012). Both women experienced professional isolation while at work. This is partly due to their position as being the school leader and due to perceptions of gender bias from neighboring male school leaders. The women found the male network difficult to invade and struggled to have their voices heard at meetings. The lack of professional and social contact with other local school leaders limited the women's voices at meetings and hindered their ability to engage in decision-making processes that affected their schools such as district professional development, inter-school exchanges and trips (Friedkin and Slater, 1994; Billett et al., 2007; Chapman, 2008; Dhillon, 2013). With improved access to information and knowledge, the women may be better positioned to meet the challenging, complex, and changing needs of their schools and its various stakeholders (Shakeshaft et al., 2007; Siciliano, 2015; Robinson et al., 2019).

However, they also had to contend with position and geographical isolation as well as philosophical and social isolation. While Grace admitted she was self-sufficient and wellsupported by her family, Susan's social isolation compounded her sense of loneliness and isolation, which in turn, affected her mental health. The findings suggest that when school leaders are working in complex, challenging schools such as turnarounds, they require access to various support structures, such as guidance and mentoring from other leaders who have experienced similar situations. The evidence from my findings also indicates the importance of leaders establishing their own network of "trusted" colleagues and advisors which may help toward reducing feelings of professional and social isolation (Dussault and Barnett, 1996; Gardiner et al., 2000; Piggot-Irvine, 2004; Patuawa, 2007; Grogan and Shakeshaft, 2011; Hadfield and Jopling, 2012; Robinson et al., 2019). I would advocate for government agencies charged with school intervention processes to consider how they might initiate and broker individualized support, guidance, and professional learning for school leaders leading turnaround schools.

School leadership is a relational practice (Price, 2015; Branson and Marra, 2019) and it is contextually and culturally specific (Bishop et al., 2014; Harris and Jones, 2016; Angelle, 2017; Notman et al., 2017). However, the findings from my research suggests that the relationship between the leader and appointee seldom receives enough care nor attention. Establishing and sustaining a trusting relationship between the school leader and those tasked with supporting the school to address the issues facing a high-needs school requires work and effort (Bryk and Schneider, 2003; Kutsyuruba et al., 2010; Morris, 2014;
Lee, 2015; McNae and Cook, 2017). Part of this relationship is acknowledging and surfacing the tensions between working parties (Cardno, 2007; Clandinin et al., 2009). School leaders must be given the time and space to develop relationships if a school is to advance.

Without further research in the situation at Matai School and Susan's relationship with the statutory appointee, it is difficult to determine whether aspects of the glass ceiling and cliff theory were present. It is possible to infer, based on Susan's comments about the appointee, that the appointee possibly did initiate processes that ensured Susan's leadership experience, competency, and skills were challenged (Eagly and Carli, 2003; Eagly, 2005; Thomson, 2009; Glass and Cook, 2016; Weiner and Burton, 2016; Wyland, 2016). It is not surprising then, that Susan was apprehensive about working with this appointee. Finnigan and Daly (2017) say change and even resistance to change can "create a sense of instability and disrupt routines" (p. 25). Susan's resistance to change may have caused her to reassess her views, beliefs, and values, thus causing discomfort and adding to the difficulty she experienced in accepting and engaging with change (Garcia et al., 2014).

Additionally, it is possible that issues of gender and control were present (Grogan and Shakeshaft, 2011). In the appointee's role as commissioner of Matai School, he was required to work with Susan as an equal. Thus, it is feasible that the main issues Susan experienced with the appointee were pertaining to genderbias, control, and power, rather than personality (Harris and Jones, 2018). It is also possible this appointee leads from a "heroic" leader stance where he is the "white knight" swooping in to single-handedly save the school (Starr, 2014). That Susan was fighting him on this and a number of other issues may have presented unexpected countervailing pressures for the appointee. Cardno (2007) advices people to "acknowledge and confront dilemmas and attempt their resolution" (p. 33) when conflict or resistance is present, otherwise it becomes difficult for people and organizations to move forward. The lack of a professional trusting relationship (Grogan and Shakeshaft, 2011; Qian and Walker, 2014; Augustine-Shaw et al., 2017) between Susan and the appointee significantly constrained Susan's engagement with Matai School's statutory intervention.

Likewise, it is difficult to identify whether Grace's appointment to Pohutukawa School might be considered a glass cliff response to the school's challenging situation (Haslam and Ryan, 2008; Ryan and Haslam, 2009; Bruckmüller and Branscombe, 2010; Ryan et al., 2011). The [women] appointee at Pohutukawa School was charged with the responsibility of appointing a school leader best suited to the school; as such, assumptions of gender-bias are unfounded. As Grace shared, she applied for the position having confidence in her skills, knowledge, and experience, to turn around the school. Further, she had historical whannau ties to the area. It is possible her connection with the people, land, and culture surrounding Pohutukawa School and community enabled her to feel welcomed in the community, thus enhancing her protectiveness of the community when engaging in conversations with other school leaders. Noddings (2013) argues that women in particular, will consider whether others demonstration of positive level of care toward them. They will 
compare these levels with their own "attitude of caring" and their "memories and feelings" of care (Noddings, 2013, p. 29).

Consequently, might also be possible that Susan's difficulties with the male appointee stem from the dichotomy between Susan's relational care for Matai School's stakeholders and the appointee's seemingly lack of relational care. While the women acknowledged the importance of relational practices, they acknowledge the emotional labor required was very taxing (Cavanagh et al., 2012; Carpenter, 2015; Augustine-Shaw et al., 2017; Holmes, 2017; McNae and Cook, 2017).

Leading a school through an intervention negatively affected the participant school leaders' psychological and physiological health. Susan's experiences highlight how severely a leader's psychological and physiological health can be compromised through the stress and worry brought on by their school's situation. Susan's predicament correlates to the findings of the 2016 NZEI survey on primary principal health. Riley (2017) report as well as the findings of the Australian surveys (Riley and Langan-Fox, 2013; Riley, 2014, 2015) and other small-scale New Zealand research, indicates primary school leaders experience high levels of stress-related illnesses (Hodgen and Wylie, 2005; Patuawa, 2007). This may offer insights why (Beatty, 2007) work acknowledges that most school leaders hide behind their professional identity and "bury" their personal selves under the demands and expectations of their work.

School leadership is a challenging and complex task. When a school is undergoing an intervention, complexity and challenges can increase, requiring leaders to draw upon deeper levels of personal "capacity, confidence, and [emotional] resilience" (Branson, 2011, p. 44). For Susan and Grace, the support they received from their whanau (family) provided a respite from the tensions of managing multiple and complex countervailing pressures. They acknowledged that without this support, they could not maintain their commitment to their schools. In Susan's instance, the support of her family ensured she did take her own life.

Fullan (2016), Futernick and Urbanski (2014), Le Floch et al. (2016), and Scott (2008) state a number of programs and processes implemented to address high-need schools, are generic and predetermined by educational authorities and those charged to bring about positive change. However, given that schools are complex organizations located in diverse communities, I would advocate these predetermined programs are not always the best way to achieve positive, sustainable outcomes (Nicolaidou and Ainscow, 2002; Marsh et al., 2013; Meyers and Smylie, 2017). Individualized programs, developed with the support of the school's stakeholders and community are vital for the longerterm sustainability and stability of the school. It is equally important that the cultural context of the school and community be identified (Bishop et al., 2014; Harris and Jones, 2016; Angelle, 2017; Notman et al., 2017) and carefully considered prior to, and during this process. Therefore, I would also advocate for these individualized programs to develop and embed contextually and culturally appropriate support structures at multiple stages of the turnaround process. Equally, it is important for government interventionists to acknowledge that the processes and actions implemented in school may be inappropriate or ineffective for another.

Evidence from this research indicates that when as school leader perceives there is a lack of ethic of care from the appointee, they question their trust in that person. Therefore, for the women leaders of turnaround schools, the relational practices and expertise of the appointee play a significant role in their ability to trust the actions of the appointee (Timperley, 2014). Kutsyuruba et al. (2010) state trust is both a learned behavior and an emotional skill. Over time, we learn to trust others through repeated interactions. Trust is an important element for the development of social relationships and underpins a moral and ethical community. Therefore, trust is an important element of school leadership, particularly in turnaround schools where there may be complex issues to address and "uncertainty has become the norm" (Sutherland, 2017, p. 2). A recommendation of this research is for those charged with supporting or leading school turnaround to provide reasonable levels of care and support to school leaders. It is vital appointees have knowledge and awareness of stress-related signs and symptoms and be prepared to facilitate appropriate support and help for school leaders. Perhaps it is also equally as important that school leaders are matched with appointees who reflect the "race, gender, and culture" (Shakeshaft et al., 2007, p. 112). Further, this appointee should also be capable to bridging the leader's entry into local professional networks. As evidenced in the findings, both women leaders struggled to find local professional women's networks, and in small rural communities, perhaps this network needs to extend outside of the education profession. Within New Zealand schools, board of trustees, as employers, are required to provide a safe and healthy environment for staff and students. This includes mental well-being (NZSTA, 2019). Therefore, when an appointee is fulfilling the duties of the board, this requirement lies with them. School leaders require support, guidance, and care. If people are prioritized above all other factors in any intervention, then our schools, and community and society will become stronger, safer places for all.

\section{CONCLUSION}

Susan and Grace have been professionally and personally shaped and changed from their experiences. They are not the same school leaders as they were at the beginning of their experiences of leading a New Zealand state primary school through a statutory intervention. The experiences of Susan and Grace highlight a need for the tensions surrounding school leadership to be surfaced. Both leaders have learnt about more themselves professionally and personally. For Susan, this was how to be a school leader and manager and how to delegate responsibilities and roles to others, to distribute leadership and to make time for herself. Self-learning and professional leadership development comes from the strangest of places. The opportunity to turn a school around, while demanding also provided opportunities for both women to reflect, grow and affirm their leadership. They are more aware of their personal abilities and limitations, particularly in relation to complex and challenging situations. 
Grace shared she had learnt a lot from the Pohutukawa School, and she had learnt a lot about herself and the things she was not prepared to compromise on. She especially learnt the importance of taking time to listen to others, examine and sometimes disrupt underlying discourses that prevent change or undermine socially just leadership practices and value the relationships with the school and community.

Society's perceptions of heroic or savior leaders (Mann et al., 2017) turning around schools seldom allows for the complexity of such work to be acknowledged nor addressed. As Bush (2019) suggests, it is time to move pass this view and consider the deeper implications of this work. The heroic or savior discourses do not provide the space for school leaders to acknowledge the work required to turn schools around. For turnaround school leaders to be viewed as anything other than heroic or savior, it is vital that leaders speak out about their experiences, to acknowledge and identify the countervailing pressures and demands they face while undertaking such work. It is also important they draw attention to the professional and personal cost of doing this work. It is equally important for educational authorities and researchers listen to and learn from these stories. Educationalist and researchers must disrupt the inherent silences of turnaround school leadership (Chase, 2003; Theoharis, 2007; Mazzei, 2008) by listening to the silences and interludes within school leaders narratives and seek the untold stories hidden beneath the surface. Perhaps with better understanding and acknowledgment of the hidden cost of turnaround school leadership, government intervention processes will stop focusing on swift turnaround timeframes and position people first. If prospective and current school leaders have a greater awareness of, and are more open about some of the darker aspects of school leadership (Thomson, 2009), school leaders may be better prepared to manage multiple countervailing pressures and difficult moments. It is time for the silences surrounding the darker aspects of school leadership be broken.

This research focused on two women principals leading their schools during a statutory intervention. A key criteria of my research included school size. As an ex-principal of a small, semirural school under statutory intervention, I was aware of the complexity of a teaching-principal's role and that the majority of these leaders lead without the support of a senior leadership team. I was also aware of the challenges schools experience while undergoing an intervention. It is for these reasons that I specifically focused on principals leading small schools. The challenges small-schools and the leaders experience are not the same as larger schools; these schools are not miniature versions

\section{REFERENCES}

Abrahamsen, H., and Aas, M. (2016). School leadership for the future: heroic or distributed? Translating international discourses in Norwegian policy documents. J. Educ. Adm. Hist. 48, 68-88. doi: 10.1080/00220620.2016. 1092426

ACARA (2016). National Report on Schooling in Australia 2013: Measuring Performance. ACARA Australian Curriculum, Assessment and Reporting Authority. Avaliable online at: http://www.acara.edu.au/reporting/national- of large schools" (Dinham et al., 2011, p. 149). As evidenced by Susan and Grace, the pressures and challenges of leading a small school through an intervention are numerous.

Ehara taku toa $i$ te toa takitahi engari he toa takimano

My strength is not that of an individual but that of the collective

(Māori proverb)

\section{DATA AVAILABILITY STATEMENT}

The datasets generated for this study are available on request to the corresponding author.

\section{ETHICS STATEMENT}

Written informed consent was obtained from the individuals for the publication of any potentially identifiable images or data included in this article.

\section{AUTHOR CONTRIBUTIONS}

The author confirms being the sole contributor of this work and has approved it for publication.

\section{FUNDING}

This research was made possible by a TeachNZ Primary Principals' and Teachers' Study Award and a University of Waikato Doctoral Scholarship.

\section{ACKNOWLEDGMENTS}

I wish to acknowledge and thank Susan and Grace for sharing their experiences of leading a New Zealand primary school through a statutory intervention. I hope that when you read your stories, you see how strong you are personally and professionally. I also thank Dr. Noeline Wright and Associate Professor Rachel $\mathrm{McNae}$ for their support, supervision and encouragement during my doctorate journey. Rachel, thank you for advice and words of wisdom as I wrote this chapter. I would like to acknowledge the two reviewers for providing useful and detailed comments that prompted me to make substantial revisions to an earlier draft.

Porokaiwhiri School, Susan and Matai School, and Grace and Pohutukawa School are all pseudomonas. The schools are named after New Zealand trees that are growing within the vicinity of the participants schools. report-on-schooling-in-australia-2013/national-policy-context/measuringperformance

Ahumada, L., Galdames, S., and Clarke, S. (2016). Understanding leadership in schools facing challenging circumstances: a chilean case study. Int. J. Leadersh. Educ. 19, 264-279. doi: 10.1080/13603124.2015.1048744

Ainscow, M., West, M., and Nicolaidou, M. (2005). "Putting our heads together: a study of headteacher collaboration as a strategy for school improvement," in Improving Schools in Difficulty, ed P. Clarke (London: Continuum International Publishing Group), 117-136. 
Angelle, P. S. (2017). "The enactment of social justice," in A Global Perspective of Social Justice Leadership For School Principals, ed P. S. Angelle (Charlotte, NC: Information Age Publishing), 65-84.

Augustine-Shaw, D., Hachiya, R., and Northern Miller, T. (2017). "Leadership for change," in Quandaries of School Leadership: Voices from Principals in the Field, eds D. J. Touchton, M. A. Rodríguez, G. Ivory, and M. Acker-Hocevar (Cham: Palgrave Macmillan US), 207-223.

Barker, B. (2011). Turnaround leadership: how three successful leaders turned around their schools (Ph.D. thesis). Master of Educational Leadership and Management, Unitec Institute of Technology. Available online at: http://unitec. researchbank.ac.nz/handle/10652/1871

Barkuizen, G., Benson, P., and Chik, A. (2014). Narrative Inquiry in Language Teaching and Learning Research. New York, NY: Routledge.

Bauer, S. C., and Brazer, S. D. (2013). The impact of isolation on the job satisfaction of new principals. J. School Leadersh. 23, 152-177. doi: $10.1177 / 105268461302300106$

Bauer, S. C., and Silver, L. (2018). The impact of job isolation on new principals' sense of efficacy, job satisfaction, burnout and persistence. J. Educ. Administr. 56, 315-331. doi: 10.1108/JEA-07-2017-0078

Bauer, S. C., Silver, L., and Schwartzer, J. (2019). The Impact of isolation on new principals' persistence: evidence from a southern US state. Educ. Manag. Administr. Leadersh. 47, 383-399. doi: 10.1177/1741143217739359

Beatty, B. R. (2000). The emotions of educational leadership: breaking the silence. Int. J. Leadersh. Educ. 3, 331-357. doi: 10.1080/1360312007500 35969

Beatty, B. R. (2007). Going through the emotions: leadership that gets to the heart of school renewal. Austr. J. Educ. 51, 328-340. doi: $10.1177 / 000494410705100309$

Beausaert, S., Froehlich, D. E., Devos, C., and Riley, P. (2016). Effects of support on stress and burnout in school principals. Educ. Res. 58, 347-365. doi: 10.1080/00131881.2016.1220810

Berkovich, I., and Grinshtain, Y. (2018). Typology of "tough love" leadership in urban schools facing challenging circumstances. Urban Educ. 16, 10-13. doi: $10.1177 / 0042085918801883$

Berwick, C. (2015). How One Country Managed to Turn Around Its Failing Schools: the Great German School Turnaround. The Atlantic. Avaliable online at: https://www.theatlantic.com/education/archive/2015/11/great-germanscool-turnaround/413806/

Billett, S., Ovens, C., Clemans, A., and Seddon, T. (2007). Collaborative working and contested practices: forming, developing and sustaining social partnerships in education. J. Educ. Policy 22, 637-656. doi: 10.1080/02680930701625288

Bishop, R., Ladwig, J., and Berryman, M. (2014). The centrality of relationships for pedagogy: the whanaungatanga thesis. Am. Educ. Res. J. 51, 184-214. doi: 10.3102/0002831213510019

Blackmore, J. (2013). A feminist critical perspective on educational leadership. Int. J. Leadersh. Educ. 16, 139-154. doi: 10.1080/13603124.2012.754057

Bold, C. (2012). Using Narrative in Research. Thousand Oaks, CA: SAGE Publications.

Bouchamma, Y. (2012). Leadership practices in effective schools in disadvantaged areas of Canada. Educ. Res. Int. 2012:16. doi: 10.1155/2012/712149

Branson, C. M. (2011). "Exploring the relational side of authentic leadership," in 16th Annual Values and Leadership Conference (Victoria, BC)

Branson, C. M., and Marra, M. (2019). Leadership as a relational phenomenon: what this means in practice. Res. Educ. Administr. Leadersh. 4, 81-108. doi: $10.30828 / \mathrm{real} / 2019.1 .4$

Braun, V., and Clarke, V. (2006). Using thematic analysis in psychology. Qual. Res. Psychol. 3, 77-101. doi: 10.1191/1478088706qp063oa

Bruckmüller, S., and Branscombe, N. R. (2010). The glass cliff: when and why women are selected as leaders in crisis contexts. Br. J. Soc. Psychol. 49, 433-451. doi: 10.1348/014466609X466594

Bruckmüller, S., Ryan, M. K., Rink, F., and Haslam, S. A. (2014). Beyond the glass ceiling: the glass cliff and its lessons for organisational policy. Soc. Issues Policy Rev. 8, 202-232. doi: 10.1111/sipr.12006

Bryk, A. S., and Schneider, B. (2003). Trust in schools: a core resource for school reform. Educ. Leadersh. 60, 40-44.

Bush, T. (2012). "Authenticity in research: reliability, validity and triangulation," in Research Methods in Educational Leadership and Management, 3rd Edn, eds A. Briggs, M. Coleman, and M. Morrison (London: SAGE Publications Ltd), 75-89.

Bush, T. (2019). Collaborative school leadership: can it co-exist with solo leadership in high accountability settings? Educ. Manage. Administr. Leadersh. 45:174114321985320. doi: 10.1177/17411432198 53202

Busher, H., and James, N. (2012). "The ethical framework of research practice," in Research Methods in Educational Leadership and Management, 3rd Edn. eds A. Briggs, M. Coleman, and M. Morrison (London: SAGE Publications), 90-104.

Caldwell, C., Dixon, R. D., Floyd, L. A., Chaudoin, J., Post, J., and Cheokas, G. (2012). Transformative leadership: achieving unparalleled excellence. J. Bus. Ethics 109, 175-187. doi: 10.1007/s10551-011-1116-2

Cardno, C. (2007). Leadership learning: the praxis of dilemma management. ISEA $35,33-50$.

Carpenter, D. (2015). School culture and leadership of professional learning communities. Int. J. Educ. Manage. 29, 682-694. doi: 10.1108/IJEM-04-2014-0046

Cavanagh, T., Macfarlane, A., Glynn, T., and Macfarlane, S. (2012). Creating peaceful and effective schools through a culture of care. Discourse Abingdon 33, 443-455. doi: 10.1080/01596306.2012.681902

Chapman, C. (2008). Towards a framework for school-to-school networking in challenging circumstances. Educ. Res. 50, 403-420. doi: $10.1080 / 00131880802499894$

Chase, S. (2003). "Taking narrative seriously: consequences for method and theory in interview studies," in Turning Points in Qualitative Research: Tying Knots in a Handkerchief, eds Y. Lincoln, and N. Denzin (Walnut Creek, CA: AltaMira Press), 273-296.

Clandinin, D. J., and Connelly, F. M. (2000). Narrative Inquiry: Experience and Story in Qualitative Research. San Francisco, CA: Jossey-Bass.

Clandinin, D. J., and Murphy, M. S. (2007). "Looking ahead: conversations with Elliot Mishler, Don Polkinghorne, and Amia Lieblich," in Handbook of Narrative Inquiry: Mapping a Methodology, ed D. J. Clandinin (Thousand Oaks, CA: SAGE Publications Ltd), 632-650.

Clandinin, D. J., Murphy, M. S., Huber, J., and Orr, A. M. (2009). Negotiating narrative inquiries: living in a tension filled midst. J. Educ. Res. 103, 81-90. doi: 10.1080/00220670903323404

Clandinin, D. J., and Rosiek, J. (2007). "Mapping a landscape of narrative inquiry: borderland spaces and tensions," in Handbook of Narrative Inquiry: Mapping a Methodology, ed D. J. Clandinin (Thousand Oaks, CA: SAGE Publications), 35-76.

Clarke, P. (Ed.). (2005). Improving Schools in Difficulty. London: Continuum International Publishing Group.

Codd, J., Harker, R., and Nash, R. (1990). "Education, politics and the economic crisis," in Political Issues in New Zealand Education, 2nd Edn, eds J. Codd, R. Harker, and R. Nash (Palmerston North: Dunmore Press Limited), 7-22.

Collins, V. P. (2015). Listening to the Voices of African American Female Principals Leading 'Turnaround' Schools. University of Denver. Avaliable online at: https:// digitalcommons.du.edu/etd/135

Cook, A., and Glass, C. (2013). Glass cliffs and organizational saviors: barriers to minority leadership in work organizations? Soc. Probl. 60, 168-187. doi: $10.1525 /$ sp.2013.11147

Cornish, L., and Jenkins, K. (2015). "Teaching principals," in Bush Tracks, eds D. Graham and J. Miller (Rotterdam: Springer), 135-156.

Coulter, C. A. (2009). Response to comments: finding the narrative in narrative research. Educ. Res. 38, 608-611. doi: 10.3102/0013189X09354124

Crow, G. M. (2006). Complexity and the beginning principal in the United States: perspectives on socialization. J. Educ. Administr. 44, 310-325. doi: 10.1108/09578230610674930

Dewey, J. (1938). Experience and Education. New York, NY: The Macmillan Company.

Dhillon, J. K. (2013). Senior managers' perspectives of leading and managing effective, sustainable and successful partnerships. Educ. Manag. Administr. Leadersh. 41, 736-750. doi: 10.1177/1741143213494186

Dimmock, C., and Lam, M. (2012). "Grounded theory research," in Research Methods in Educational Leadership and Management, 3rd Edn, eds A Briggs, M. Coleman, and M. Morrison (London: SAGE Publications Ltd), $188-204$. 
Dinham, S., Anderson, M., Caldwell, B., and Weldon, P. (2011). Breakthroughs in school leadership development in Australia. School Leadersh. Manage. 31, 139-154. doi: 10.1080/13632434.2011.560602

Duke, D. (2014). A bold approach to developing leaders for low-performing schools. Manag. Educ. 28, 80-85. doi: 10.1177/0892020614537665

Dussault, M., and Barnett, B. G. (1996). Peer-assisted leadership: reducing educational managers' professional isolation. J. Educ. Administr. 34, 5-14. doi: $10.1108 / 09578239610118848$

Dussault, M., and Thibodeau, S. (1996). "Relationships between professional isolation of school principals and their performance at work," in Annual Meeting of the American Educational Research Association (New York, NY).

Eacott, S. (2020). The principals' workday: a relational analysis. Int. J. Leadersh. Educ. 1-14. doi: 10.1080/13603124.2020.1725645

Eagly, A. H. (2005). Achieving relational authenticity in leadership: does gender matter? Leadersh. Q. 16, 459-474. doi: 10.1016/j.leaqua.2005.03.007

Eagly, A. H., and Carli, L. L. (2003). The female leadership advantage: an evaluation of the evidence. Leadersh. Q. 14, 807-834. doi: 10.1016/j.leaqua.2003. 09.004

Eagly, A. H., and Sczesny, S. (2009). "Stereotypes about women, men, and leaders: have times changed?" in The Glass Ceiling in the 21st Century: Understanding Barriers to Gender Equality, eds M. Barreto, M. K. Ryan, and M. T. Schmitt (Washington, DC: American Psychological Association), 21-47.

Education Review Office (1999). Small Primary Schools (Wellington).

Education Review Office (2016). Return Times for School Review (Wellington).

Education Scotland Foghlam Alba (2017). Primary School Inspections. Education Scotland Foghlam Alba. Avaliable online at: https://education.gov.scot/ what-we-do/inspection-and-review/about-inspections-and-reviews/Primary $\% 20$ school\%20inspections

Estyn (2018). Inspection | Estyn. Avaliable online at: https://www.estyn.gov.wales/ inspection

ETI (2015). Focus and Purpose of Inspection. Education Training Inspectorate (ETI). Avaliable online at: https://www.etini.gov.uk/articles/purpose-inspection

Fairchild, T., and DeMary, J. (2011). The Turnaround Mindset: Aligning Leadership for Student Success. Lanham, MD: Rowman and Littlefield Education.

Federici, R., and Skaalvik, E. (2012). "Teacher and principal self-efficacy: relations with autonomy and emotional exhaustion," in Perspectives on Cognitive Psychology: Self-Efficacy in School and Community Settings, ed B. Shari (Hauppauge, NY: Nova), 125-150.

Finnigan, K. S., and Daly, A. J. (2017). The trust gap: understanding the effects of leadership churn in school districts. Am. Educ. 41, 22-29, 43.

Franquiz, A. (2013). Watch out for the 'glass cliff'. HRMagazine 58:20.

Friedkin, N. E., and Slater, M. R. (1994). School leadership and performance: a social network approach. Soc. Educ. 67, 139-157. doi: 10.2307/2112701

Fullan, M. (2016). The New Meaning of Educational Change, 5th Edn. New York, NY: Routledge; Ontario Principals' Council.

Futernick, K., and Urbanski, A. (2014). "Successful school turnarounds through labour-management partnerships: the role of state education agencies," in The State Role in School Turnaround: Emerging Best Practice, eds L. Morando Rhim and S. Redding (San Francisco, CA: WestEd), 65-80.

Garcia, A. S., Morrison, K., Tsoi, A. C., and He, J. (2014). Managing Complex Change in School: Engaging Pedagogy, Technology, Learning and Leadership. London: Routledge.

Gardiner, M. E., Enomoto, E., and Grogan, M. (2000). Coloring Outside the Lines: Mentoring Women into School Leadership. Ithaca, NY: State University of New York Press.

Glaser, B. G. (1978). Theoretical Sensitivity: Advances in the Methodology of Grounded Theory. Mill Valley, CA: Sociology Press.

Glass, C., and Cook, A. (2016). Leading at the top: understanding women's challenges above the glass ceiling. Leadersh. Q. 27, 51-63. doi: 10.1016/j.leaqua.2015.09.003

Goddard, J. T. (2003). "Leadership in the (post) modern era," in Rethinking Educational Leadership: Challenging the Conventions, eds N. Bennett and L. Anderson (London: SAGE Publications), 20-33.

Gold, Y. (1984). Burnout: a major problem for the teaching profession. Education $104,271-274$.

Goldstein, H., and Woodhouse, G. (2000). School effectiveness research and educational policy. Oxford Rev. Educ. 26, 353-363. doi: 10.1080/713688547
Grayson, J. L., and Alvarez, H. K. (2008). School climate factors relating to teacher burnout: a mediator model. Teach. Teach. Educ. 24, 1349-1363. doi: 10.1016/j.tate.2007.06.005

Grogan, M., and Shakeshaft, C. (2011). Women and Educational Leadership. San Francisco, CA: Jossey-Bass.

Grogan, M. (2002). Influences of the discourse of globalisation on mentoring for gender equity and social justice in educational leadership. Lead. Manag. Auckland, 8, 123-134.

Gupton, S., and Del Rosario, R. M. (1998). An analyses of Federal initiatives to support women's upward mobility in educational administration. Adv Women Leadersh. 1, 123-134. Available online at: https://search-informit-comau.ezproxy.waikato.ac.nz/fullText; $\mathrm{dn}=135797 ;$ res=AEIPT

Hadfield, M., and Jopling, M. (2012). How might better network theories support school leadership research? School Leadersh. Manag. 32, 109-121. doi: 10.1080/13632434.2012.670115

Hadley, S. A., and MacLeod, A. K. (2010). Conditional goal-setting, personal goals and hopelessness about the future. Cogn. Emotion 24, 1191-1198. doi: 10.1080/02699930903122521

Hallinger, P., and Heck, R. H. (2011). Exploring the journey of school improvement: classifying and analyzing patterns of change in school improvement processes and learning outcomes. Sch. Eff. Sch. Improv. 22, 1-27. doi: 10.1080/09243453.2010.536322

Halsey, R. J. (2011). Small schools, big future. Austr. J. Educ. 55, 5-13. doi: $10.1177 / 000494411105500102$

Harris, A. (2002). Effective leadership in schools facing challenging contexts. Sch. Leadersh. Manag. 22, 15-26. doi: 10.1080/13632430220143024a

Harris, A. (2003). Introduction: challenging the orthodoxy of school leadership: towards alternative theoretical perspectives. Sch. Leadersh. Manag. 23, 125-128. doi: 10.1080/1363243032000091913

Harris, A., and Jones, M. (2018). The dark side of leadership and management. Sch. Leadersh. Manag. 38, 475-477.

Harris, A., and Jones, M. (2016). "International comparisons: critique, culture and context," in Leading Futures: Global Perspectives on Educational Leadership, eds A. Harris and M. Jones (SAGE Publications India Pvt Ltd), xiii-xxxii.

Haslam, S. A., and Ryan, M. K. (2008). The road to the glass cliff: differences in the perceived suitability of men and women for leadership positions in succeeding and failing organizations. Leadersh. Q. 19, 530-546. doi: 10.1016/j.leaqua.2008.07.011

Henn, M., Weinstein, M., and Foard, N. (2009). A Critical Introduction to Social Research, 2nd Edn. Los Angeles, CA: SAGE.

Herlihy, B., and Herlihy, D. (1980). The loneliness of educational leadership. NASSP Bull. 64, 7-12. doi: 10.1177/019263658006443302

Hodgen, E., and Wylie, C. (2005). Stress and Wellbeing Among New Zealand Principals: Report to the New Zealand Principal Federation, 1-12. New Zealand Council for Educational Research. Available online at: http://www.nzpf.ac.nz/ uploads/7/2/4/6/72461455/section1.pdf

Holmes, J. (2017). "Leadership and change management: examining gender, cultural and 'hero leader' stereotypes," in Challenging Leadership Stereotypes Through Discourse: Power, Management and Gender, eds C. Ilie and S. Schnurr (Singapore: Springer), 15-43.

Howard, M., and Mallory, B. (2008). Perceptions of isolation among high school principals. J. Women Educ. Leadersh. 6, 1541-6224. at: http://www. digitalcommons.unl.edu/jwel/32

Izgar, H. (2009). An investigation of depression and loneliness among school principals. Kuram Uygulamada Egitim Bilim. 9, 247-258.

Jang, E. E., McDougall, D. E., Pollon, D., Herbert, M., and Russell, P. (2008). Integrative mixed methods data analytic strategies in research on school success in challenging circumstances. J. Mix. Methods Res. 2, 221-247. doi: $10.1177 / 1558689808315323$

Jongewaard, S. (2006). Teachers at Risk: Preparing Effective Teachers for 21st Century Schools. Available online at: http://www.agi.harvard.edu/Search/ download.php?id=118

Josselson, R. (2013). Interviewing for Qualitative Inquiry: A Relational Approach. New York, NY: The Guilford Press.

Kelchtermans, G., Piot, L., and Ballet, K. (2011). The lucid loneliness of the gatekeeper: exploring the emotional dimension in principals' work lives. Oxford Rev. Educ. 37, 93-108. doi: 10.1080/03054985.2010.545192 
Kelehear, Z. (2004). Controlling stress. Principal Leadersh. Middle Level Ed. Reston, $5,30-33$.

Kelly, A., and Clarke, P. (2016). "Challenges of globalisation and the new policy paradigms for EEIR," in The Routledge International Handbook of Educational Effectiveness and Improvement: Research, Policy and Practice, eds C. Chapman, D. Muijs, D. Reynolds, P. Sammons, and C. Teddlie (Routledge), 365-379.

Kelsey, J. (1997). The New Zealand Experiment: A World Model for Structural Adjustment? Auckland: Auckland University Press.

Knox, S., and Burkard, A. W. (2009). Qualitative research interviews. Psychother. Res. 19, 566-575. doi: 10.1080/10503300802702105

Kowal, J., and Ableidinger, J. (2011). Leading Indicators of School Turnarounds: How to Know When Dramatic Change Is on Track, 28. University of Virginia's Darden/Curry Partnership for Leaders in Education. Available online at: www. DardenCurry.org

Kulich, C., Lorenzi-Cioldi, F., Iacoviello, V., Faniko, K., and Ryan, M. K. (2015). Signaling change during a crisis: refining conditions for the glass cliff. J. Exp. Soc. Psychol. 61, 96-103. doi: 10.1016/j.jesp.2015.07.002

Kutash, J., Nico, E. R., Malenfant, E., Rahmatullah, S., and Tallant, K. (2010). School Turnaround Field Guide. FSG. Avaliable online at: https://www.fsg.org/toolsand-resources/school-turnaround-field-guide

Kutsyuruba, B., Walker, K., and Noonan, B. (2010). The ecology of trust in the principalship. EAF J. 21:23.

Kvale, S. (2007). Doing Interviews. Los Angeles, CA: Sage Publications.

Lauder, H., Wylie, C., and Parker-Taunoa, R. (2012). "Citizens or consumers? the politics of educational reform: an introduction," in Towards Successful School, eds H. Lauder and C. Wylie (London: Routledge), 1-14.

Le Floch, K. C., O’Day, J., Birman, B., Hurlburt, S., Nayfack, M., Halloran, C., et al. (2016). Case Studies of Schools Receiving School Improvement Grants. Final Report (NCEE 2016-4002). National Center for Education Evaluation and Regional Assistance; Institute of Education Sciences; U.S. Department of Education. Available online at: http://ies.ed.gov/ncee

Lee, L. C. (2015). School performance trajectories and the challenges for principal succession. J. Educ. Administr. 53, 286-262. doi: 10.1108/JEA-12-2012-0139

Leithwood, K., Harris, A., and Strauss, T. (2010). Leading School Turnaround: How Successful Leaders Transform Low-Performing Schools. Thousand Oaks, CA: Jossey-Bass.

Leithwood, K., and Beatty, B. R. (2008). Leading With Teacher Emotions in Mind. Thousand Oaks, CA: Corwin Press.

Lewins, A., Taylor, C., and Gibbs, G. R. (2010). What is Qualitative Data Analysis (QDA) [Online QDA Web Site]. Avaliable online at: http://onlineqda.hud.ac.uk/ Intro_QDA/what_is_qda.php

Liljenberg, M., and Andersson, K. (2019). Novice principals' attitudes toward support in their leadership. Int. J. Leadersh. Educ. 1-18. doi: $10.1080 / 13603124.2018 .1543807$

Lindorff, M. (2001). Are they lonely at the top? social relationships and social support among Australian managers. Work Stress 15, 274-282. doi: $10.1080 / 026783701110.1080 / 02678370110066599$

Linn, G. B. (2011). A (super) heroic vision of leader self. J. Leadersh. Educ. 10, 172-179. doi: 10.12806/V10/I2/AB1

Liu, P. (2018). Understanding turnaround leadership research: continuity and change (2009-2016). Educ. Manag. Administr. Leadersh. 48, 6-24. doi: $10.1177 / 1741143218807490$

Lochmiller, C. R., and Chesnut, C. E. (2017). Preparing turnaround leaders for high needs urban schools. J. Educ. Administr. 55, 85-102. doi: 10.1108/JEA-11-2015-0099

Lock, G., Budgen, F., Lunay, R., and Oakley, G. (2012). The loneliness of the longdistance principal: tales from remote Western Australia. Austr. Int. J. Rural Educ. 22, 65-77.

Lynch, M. (2012). A Guide to Effective School Leadership Theories. New York, NY: Routledge.

Manion, C. (2008). Is there a match between the Education Review Office's identification of concerns and the Ministry of Education's statutory intervention in schools on supplementary review in specific case studies? (M.Ed. thesis). University of Waikato, Hamilton, New Zealand.

Mann, E., Herman, R., and Hansen, M. (2017). "Should they stay or should they go? the mythical appeal of staff replacement as a turnaround strategy," in Enduring Myths That Inhibit School Turnaround, eds C. V. Meyers and M. J. Darwin (Charlotte, NC: Information Age Publishing), 253-273.
Marsh, J., Strunk, K., and Bush, S. (2013). Portfolio district reform meets school turnaround. J. Educ. Administr. 51, 498-527. doi: 10.1108/095782313113 25677

Mazzei, L. (2008). "An impossibly full voice," in Voice in Qualitative Inquiry: Challenging Conventional, Interpretive, and Critical Conceptions in Qualitative Research, eds A. Jackson and L. Mazzei (Florence, SC: Routledge), $45-62$.

McNae, R., and Cook, S. (2017). "Leading turnaround schools: surfacing hope in times of crisis," in Educational Leadership in Aotearoa New Zealand: Issues of Context and Social Justice, eds R. McNae, M. Morrison, and R. Notman (Wellington: NZCER Press), 29-45.

Medina, V., Martinez, G., Murakami, E. T., Rodriguez, M., and Hernandez, F. (2014). Principals' perceptions from within: leadership in high-need schools in the USA. Manag. Educ. 28, 91-96. doi: 10.1177/0892020614537664

Meyers, C. V., and Smylie, M. A. (2017). Five myths of school turnaround policy and practice. Leadersh. Policy Sch. 16, 502-523. doi: 10.1080/15700763.2016.1270333

Mills, M., and Niesche, R. (2014). School reform and the emotional demands of principals: Lorna's story. Sch. Leadersh. Manag. 34, 120-135. doi: 10.1080/13632434.2013.856295

Ministry of Education (2008). Kiwi Leadership for Principals: Principal as Educational Leaders.

Ministry of Education (2013). Interventions: Guide for Schools. Avaliable online at: https://web.archive.org/web/20150126073328/http://www.minedu.govt.nz/ Boards/SupportForBoards/InterventionsInSchools/InterventionsInSchools. aspx

Ministry of Education (2014a). Review of Statutory Intervention in State and State Integrated Schools: Discussion Paper. Avaliable online at: http://www.nzpf. ac.nz/uploads/7/2/4/6/72461455/moe_discussion_paper_sector_review_of_ statutory_interventions.pdf

Ministry of Education (2014b). Review of Statutory Interventions in State Schools and State Integrated Schools: Final Report and Recommendations to the Minister of Education. Avaliable online at: http://www.minedu. govt.nz/Boards/SupportForBoards/InterventionsInSchools/Review.aspx (link no longer available)

Ministry of Education (2015). Interventions: Guide for Schools. Avaliable online at: http://www.education.govt.nz/school/running-a-school/interventions-inschools/interventions-guide-for-schools/

Ministry of Education (2017). Statutory services provider: Role description for roles in statutory intervention.

Ministry of Education (n.d). Schools-Te Kete Ipurangi (TKI). Avaliable online at: https://www.tki.org.nz/Schools (accessed August 2, 2016).

Moctezuma, J. A. (2017). The Lived Experience of Teachers Choosing an Arts-Rich Approach in Turnaround Schools (Ph.D. thesis). University of New Orleans, New Orleans, LA, United States.

Møller, J. (2012). The construction of a public face as a school principal. Int. J. Educ. Manag. 26, 452-460. doi: 10.1108/09513541211240246

Morris, J. (2014). The School Leadership Effect (New Zealand Education and Scholarship Trust and The New Zealand Initiative). New Zealand Education and Scholarship Trust. Avaliable online at: http://ndhadeliver.natlib.govt.nz/ delivery/DeliveryManagerServlet?dps_pid=IE24237716

Muijs, D. (2014). "Improving failing schools: towards a research-based model. stating the problem-what are failing schools?", in 20th Annual World ICSEI (International Congress for Effectiveness and Improvement, 77-90. Available online at: http://www.fm-kp.si/zalozba/ISBN/978-961-6573-65-8/077-090.pdf

Munn-Giddings, C. (2012). "Action research," in Research Methods and Methodologies in Education, eds J. Arthur, M. Waring, R. Coe, and L. Hedges (London: SAGE Publications), 71-75.

New Zealand Government (n.d). About Us-New Zealand Gazette. Avaliable online at: https://gazette.govt.nz/about-us/ (accessed August 2, 2016).

New Zealand School Trustees Association (2010a). Legislation. NZSTA. Avaliable online at: http://www.nzsta.org.nz/board-responsibilties/legislation/

New Zealand School Trustees Association (2010b). Role of a School Board of Trustees. NZSTA. Avaliable online at: http://www.nzsta.org.nz/board-asgovernors/role-of-the-board/

Nicolaidou, M. (2005). "What is special about special measures? Perspectives from the inside," in Improving Schools in Difficulty, ed P. Clarke (Continuum International Publishing Group), 56-80. 
Nicolaidou, M., and Ainscow, M. (2002). "Understanding 'failing' schools: the role of culture and leadership," in British Research Association Annual Conference (Exeter: University of Exeter).

Nicolaidou, M., and Ainscow, M. (2005). Understanding failing schools: perspectives from the inside. Sch. Effect. Sch. Improve. 16, 229-248. doi: 10.1080/09243450500113647

Noddings, N. (2013). Caring: A Relational Approach to Ethics and Moral Education. Berkeley, CA: University of California Press.

Northfield, S. (2014). Multi-dimensional trust: how beginning principals build trust with their staff during leader succession. Int. J. Leadersh. Educ. 17, 410-441. doi: 10.1080/13603124.2013.825011

Northfield, S., Macmillan, R., and Meyer, M. J. (2011). "Trust during transition: strategic leadership and trust development during principal succession," in Principals in Succession: Transfer and Rotation in Educational Administration, eds R. E. White and K. Cooper (Dordrecht: Springer Netherlands), 109-137.

Northfield, S., Macmillan, R. B., and Meyer, M. J. (2006). Strategic leadership during principal succession. EAF J. 17, 72-94.

Notman, R., Morrison, M., and McNae, R. (2017). "Introduction: leading for social justice and high needs in education," in Educational Leadership in Aotearoa New Zealand: Issues of Context and Social Justice, eds R. McNae, M. Morrison, and R. Notman (Wellington: NZCER Press), 1-13.

Notman, R. (2015). Leadership in New Zealand high-needs schools: an exploratory study from the International School Leadership Development Network project. Scottish Educ. Rev. 47, 28-48.

NZSTA (2019). Understanding Health and Safety. Avaliable online at: https://www. nzsta.org.nz/health-and-safety/

Office of the Auditor-General (2010). Performance Audits From 2008: Follow-Up Report. Office of the Auditor-General. Avaliable online at: http://www.oag.govt. $\mathrm{nz} / 2010 /$ performance-audits/docs/performance-audits.pdf

Office of the Auditor-General (2008). Ministry of Education: Monitoring and Supporting School Boards of Trustees (Wellington).

Ofsted (2017). School Inspection Handbook: Handbook for Inspecting Schools in England Under Section 5 of the Education Act 2005 (No. 150066). Office for Standards in Education, Children's Services and Skills (Ofsted). Avaliable online at: https:/www.gov.uk/government/uploads/system/uploads/ attachment_data/file/678967/School_inspection_handbook_section_5

Ollerenshaw, J. A., and Creswell, J. W. (2002). Narrative research: a comparison of two restorying data analysis approaches. Qual. Inq. 8, 329-347. doi: $10.1177 / 10778004008003008$

Oplatka, I. (2002). Women principals and the concept of burnout: an alternative voice? Int. J. Leadersh. Educ. 5, 211-226. doi: 10.1080/136031200112873

Oplatka, I. (2017). 'I'm so tired and have no time for my family: the consequences of heavy workload in principalship. Int. Stud. Educ. Administr. CCEAM $45,21-41$.

Papa, R., and English, F. (2011). Turnaround Principals for Underperforming Schools. Lanham, MD: Rowman and Littlefield Education.

Patton, M. (ed) (2002). Qualitative Research and Evaluation Methods, 3rd Edn. Thousand Oaks, CA: SAGE Publications.

Patton, M. (2015). Qualitative Research and Evaluation Methods: Integrating Theory and Practice, 4 th Edn. Thousand Oaks, CA: SAGE Publications Ltd.

Patuawa, J. M. (2007). Principal voice: triumphs, trials and training. The experience of beginning in principalship from the perspectives of principals in years $3-5$ (Ph.D. thesis). University of Waikato, Hamilton, New Zealand.

Peck, C., and Reitzug, U. C. (2014). School turnaround fever: the paradoxes of a historical practice promoted as a new reform. Urban Educ. 49, 8-38. doi: $10.1177 / 0042085912472511$

Pelias, R. (2011). "Writing into position: strategies for composition and evaluation," in The SAGE Handbook of Qualitative Research, 4th Edn, eds N. Denzin and Y. Lincoln (Thousand Oaks, CA: SAGE Publications), 659-668.

Pepper, M. J., London, T. D., Dishman, M. L., and Lewis, J. L. (2010). Leading Schools During Crisis: What School Administrators Must Know. Lanham, MD: Rowman and Littlefield Education.

Phillips, S., and Sen, D. (2011). "Stress in head teachers," in Handbook of Stress in the Occupations: New Horizons in Management, eds J. Langan-Fox, and C. Copper (Cheltenham: Edward Elgar Publishing), 177-200.

Piggot-Irvine, E. (2004). Growth, development and a way out of principalship's isolation. Manag. Educ. 18, 24-29. doi: 10.1177/08920206040180010501
Polkinghorne, D. E. (1995). Narrative configuration in qualitative analysis. Int. J. Qualitative Stud. Educ. 8, 5-23. doi: 10.1080/09518399500 80103

Pratt-Adams, S., and Maguire, M. (2009). Urban primary school headship in England: an emotional perspective. Crit. Stud. Educ. 50, 115-127. doi: $10.1080 / 17508480902859425$

Price, H. E. (2015). Principals' social interactions with teachers: how principalteacher social relations correlate with teachers' perceptions of student engagement. J. Educ. Administr. 53, 116-139. doi: 10.1108/JEA-02-2014-0023

Qian, H., and Walker, A. (2014). "Leading with empathy," in Handbook of Ethical Educational Leadership, eds C. M. Branson, and S. J. Gross (London: Routledge), 112-127.

Ranson, S. (2008). The changing governance of education. Educ. Manag. Administr. Leadersh. 36, 201-219. doi: 10.1177/17411432070 87773

Raymond, J. M. (2007). Lonely at the top. Sch. Administr. 64:61.

Redding, S., and Morando Rhim, L. (2014). "Introduction to the state role in school turnaround: Emerging best practice," in The State Role in School Turnaround: Emerging Best Practices, eds L. Morando Rhim, and S. Redding (San Francisco, CA: WestEd), 13-18.

Redmond, A. (2017). One in 16 schools has government intervention in three years. Stuff National. Avaliable online at: https:/www.stuff.co.nz/national/education/ 89899426/one-in-16-schools-has-government-intervention-in-three-years

Reynolds, D. (1995). The Ineffective School, 1-30. Avaliable online at: https://files. eric.ed.gov/fulltext/ED393168

Riley, P. (2014). Principals' psychological health: It's not just lonely at the top, it's dangerous. InPsych Bull. Austr. Psychol. Soc. Ltd. 36, 12-13.

Riley, P. (2015). The Australian Principal Occupation Health, Safety and Wellbeing Survey 2015. Institute for Positive Psychology and Education; Australian Catholic University. Avaliable online at: http://www.principalhealth.org/au/ 2015_Final_Report

Riley, P. (2017). New Zealand Primary School Principals' Occupational Health and Wellbeing Survey 2016. Institute for Positive Psychology and Education; Australian Catholic University. Avaliable online at: https://www.nzei.org. nz/documents/Principals\%20Health\%20and\%20Well-Being\%20Report_ 20170120SM

Riley, P., and Langan-Fox, J. (2013). "Bullying, stress and health in school principals and medical professional: experiences at the 'front-line", in Human Frailties: Wrong Choices on the Drive to Success, eds J. Ronald, S. Burke, S. Fox, and C. Cooper (Farnham: Gower Publishing Ltd), 181-200.

Ritchie, J., Lewis, J., Elam, G., Tennant, R., and Rahim, N. (2014). "Designing and selecting samples," in Qualitative Research Practice: A Guide for Social Science Students and Researchers, 2nd Edn, eds J. Ritchie, J. Lewis, C. M. Nicholls, and R. Ormston (London: Sage Publications Ltd), 111-142.

Robinson, I., White, R., and Robinson, D. (2019). Indigenous women in educational leadership: identifying supportive contexts in Mi'kmaw Kina'matnewey. Int. J. Leadersh. Educ. 1-21. doi: 10.1080/13603124.2018.1562103

Robinson, W. S., and Buntrock, L. M. (2011). Turnaround necessities. Sch. Administr. 68, 22-27.

Ryan, G., and Bernard, R. (2003). Techniques to identify themes. Field Methods 15, 85-109. doi: $10.1177 / 1525822$ X02239569

Ryan, M. K., and Haslam, S. A. (2005). The glass cliff: Evidence that women are over-represented in precarious leadership positions. Br. J. Manage. 16, 81-90. doi: 10.1111/j.1467-8551.2005.00433.x

Ryan, M. K., and Haslam, S. A. (2009). Glass cliffs are not so easily scaled: on the precariousness of female CEOs' positions. Br. J. Manag. 20, 13-16. doi: 10.1111/j.1467-8551.2008.00598.x

Ryan, M. K., Haslam, S. A., Hersby, M. D., and Bongiorno, R. (2011). Think crisisthink female: the glass cliff and contextual variation in the think manager-think male stereotype. J. Appl. Psychol. 96, 470-484. doi: 10.1037/a0022133

Sachs, J., and Blackmore, J. (1998). You never show you can't cope: women in school leadership roles managing their emotions. Gender Educ. 10, 265-279. doi: 10.1080/09540259820899

Sayce, D., and Lavery, S. D. (2013). "Beginning the school principalship in rural and remote Catholic Schools in Western Australia. Paradox and Possibility," in 6th International Conference on Catholic Education Leadership (Fremantle: The 
University of Notre Dame). Available online at: http://researchonline.nd.edu. au/edu_conference/61

Scott, C. (2008). A call to restructure restructuring: lessons from the no Child left behind Act in five States. Center Educ. Policy. 33. Available online at: https:// eric.ed.gov/?id=ED503798

Segal, J., Smith, M., Robinson, L., and Segal, R. (2017). Stress in the Workplace: Managing Job and Workplace Stress. Avaliable online at: https://www.helpguide. org/articles/stress/stress-in-the-workplace.htm

Shakeshaft, C., Brown, G., Irby, B., Grogan, M., and Ballenger, J. (2007). "Increasing gender equity in educational leadership," in Handbook for Achieving Gender Equity Through Education, 2nd Edn, eds S. Klein, B. Richardson, D. Grayson, L. Fox, D. Pollard, and C. Dwyer (New York, NY: Taylor and Francis), 133-160.

Shulman, V., and Sullivan, S. (2015). Here today gone tomorrow: conceptualizing instructional leadership through case studies of unsustained initiatives. Educ. Urban Soc. 47, 271-283. doi: 10.1177/0013124513495271

Siciliano, M. D. (2015). Professional networks and street-level performance: how public school teachers' advice networks influence student performance. Am. Rev. Public Administr. 47, 79-101. doi: 10.1177/0275074015577110

Smarick, A. (2010). The turnaround fallacy. Educ. Next 10, $20-27$.

Southworth, G. (1998). Leading Improving Primary Schools: The Work of Headteachers and Deputy Heads. London: Falmer Press.

Sparrowe, R. T. (2005). Authentic leadership and the narrative self. Leadersh. Q. 16, 419-439. doi: 10.1016/j.leaqua.2005.03.004

Spillane, J. P. (2005). Distributed leadership. Educ. Forum 69, 143-150. doi: $10.1080 / 00131720508984678$

Spillane, J. P., and Lee, L. C. (2014). Novice school principals' sense of ultimate responsibility: Problems of practice in transitioning to the principal's office. Educ. Administr. Q. 50, 431-465. doi: 10.1177/0013161X13505290

Starr, K. (2011). Principals and the politics of resistance to change. Educ. Manag. Administr. Leadersh. 39, 646-660. doi: 10.1177/1741143211416390

Starr, K. (2014). Interrogating conceptions of leadership: school principals, policy and paradox. Sch. Leadersh. Manag. 34, 224-236. doi: $10.1080 / 13632434.2014 .905466$

Starr, K., and White, S. (2008). The small rural school principalship: key challenges and cross-school responses. J. Res. Rural Educ. 23, 1-12.

Stephenson, L. E., and Bauer, S. C. (2010). The role of isolation in predicting new principals' burnout. Int. J. Educ. Policy Leadersh. 5, 25-42. doi: $10.22230 /$ ijepl.2010v5n9a275

Stotsky, S., and Holzman, T. (2015a). Is 'turnaround' a useful model for lowperforming schools? Nonpartisan Educ. Rev. 11, 1-16.

Stotsky, S., and Holzman, T. (2015b). The costs of Federal intervention in local education: the effectiveness of America's Choice in Arkansas. Nonpartisan Educ. Rev. 11, 1-16. Available online at: https://nonpartisaneducation.org/ Review/Articles/v11n2.pdf

Sutherland, I. E. (2017). Learning and growing: trust, leadership, and response to crisis. J. Educ. Administr. 55, 2-17. doi: 10.1108/JEA-10-2015-0097

Theoharis, G. (2007). Navigating rough waters: a synthesis of the countervailing pressures against leading for social justice. J. Sch. Leadersh. 17, 4-27. doi: $10.1177 / 105268460701700101$

Thomson, P. (2009). School Leadership-Heads on the Block? London: Taylor and Francis Group

Thrupp, M. (2005). 'Official school improvement' in England and New Zealand: a cautionary comparison. N. Z. Annu. Rev. Educ. 14, 39-58. doi: 10.26686/nzaroe.v0i14.1487

Timms, C., Graham, D., and Caltabiano, M. (2006). Gender implication of perceptions of trustworthiness of school administration and teacher burnout/job stress. Austr. J. Soc. Issues 41, 343-358. doi: 10.1002/j.1839-4655.2006.tb00020.x

Timperley, H. (2014). Promoting and Supporting Improvement in Schools Through External Review. Education Review Office. Available online at: http://www.
ero.govt.nz/assets/Indicators-supporting-reports/Timperley-paper-approved180816B

Tomlinson, S. (1997). Sociological perspectives on failing schools. Int. Stud. Sociol. Educ. 7, 81-98. doi: 10.1080/09620219700200006

Torrance, D., Fuller, K., McNae, R., Roofe, C., and Arshad, R. (2017). "A social justice perspective on women in educational leadership," in Cultures of Educational Leadership: Global and Intercultural Perspectives, ed P. Miller (London: Palgrave Macmillan), 25-52.

Udahemuka, M. (2016). Signal Loss: What We Know About School Performance. The New Zealand Initiative. Available online at: www.nzinitiative.org.nz

Udahemuka, M. (2017a). Amplifying Excellence: Promoting Transparency, Professionalism and Support in Schools. New Zealand Initiative. Available online at: www.nzinitiative.org.nz

Udahemuka, M. (2017b). Fair and Frank: Global Insights for Managing School Performance. The New Zealand Initiative. Available online at: www.nzinitiative. org.nz

Wallace Foundation (2013). The School Principal as Leader: Guiding Schools to Better Teaching and Learning. The Wallace Foundation. Avaliable online at: http://www.wallacefoundation.org/knowledge-center/schoolleadership/effective-principal-leadership/Pages/The-School-Principal-asLeader-Guiding-Schools-to-Better-Teaching-and-Learning.aspx

Waytz, A., Chou, E. Y., Magee, J. C., and Galinsky, A. D. (2015). Not so lonely at the top: the relationship between power and loneliness. Organ. Behav. Hum. Decis. Process. 130, 69-78. doi: 10.1016/j.obhdp.2015.06.002

Weiner, J., and Burton, L. (2017). "An enduring myth: turnaround leadership is identity neutral," in Enduring Myths that Inhibit School Turnaround, eds C. V. Meyers, and M. J. Darwin (Information Age Publishing), 233-252.

Weiner, J. M., and Burton, L. (2016). The double bind for women: exploring the gendered nature of turnaround leadership in a principal preparation program. Harv. Educ. Rev. 86, 339-365. doi: 10.17763/1943-5045-86.3.339

Wesson, L. (1998). Exploring the dilemmas of leadership: voices from the field. Advanc. Women Leadersh. J. 1. Available online at: https://www. advancingwomen.com/awl/winter98/awlv2_wesson4final.html

Wildy, H., and Clarke, S. (2012). Leading a small remote school: in the face of a culture of acceptance. Education 40, 63-74. doi: 10.1080/03004279.2012. 635057

Wyland, C. (2016). Underrepresentation of females in the superintendency in Minnesota. Plann. Chang. 47, 47-62. Available online at: https:// search-proquest-com.ezproxy.waikato.ac.nz/docview/1917343919/abstract/ C24B0C9363CE4F0BPQ/1?accountid $=17287$

Wylie, C. (2009). Tomorrow's Schools After 20 Years: Can a System Of SelfManaging Schools Live Up to Its Initial Aims? Avaliable online at: http://www. victoria.ac.nz/education/research/nzaroe/issues-index/2009/pdf/text-Wylie

Wylie, C. (2013). Improving learning opportunities: why schools can't do it on their own. Set Res. Inform. Teach. 1, 45-48. Available online at: https:// www-nzcer-org-nz.ezproxy.waikato.ac.nz/nzcerpress/set/articles/improvinglearning-opportunities-why-schools-can-t-do-it-their-own

Wylie, C. (2012). Vital Connections: Why We Need More than Self-Managing Schools. Wellington: NZCER Press.

Conflict of Interest: The author declares that the research was conducted in the absence of any commercial or financial relationships that could be construed as a potential conflict of interest.

Copyright (c) 2020 Cook. This is an open-access article distributed under the terms of the Creative Commons Attribution License (CC BY). The use, distribution or reproduction in other forums is permitted, provided the original author $(s)$ and the copyright owner(s) are credited and that the original publication in this journal is cited, in accordance with accepted academic practice. No use, distribution or reproduction is permitted which does not comply with these terms. 